Max-Planck-Institut für demografische Forschung

Max Planck Institute for Demographic Research

Konrad-Zuse-Strasse $1 \cdot$ D-18057 Rostock · GERMANY

Tel +49 (0) 3812081 - 0; Fax +49 (0) 3812081 - 202;

http://www.demogr.mpg.de

MPIDR WORKING PAPER WP 2008-018

APRIL 2008

\title{
The transition from school to work in Russia during and after socialism: change or continuity?
}

Christoph Bühler (buehler@demogr.mpg.de)

Dirk Konietzka (konietzka@demogr.mpg.de)

This working paper has been approved for release by: Vladimir M. Shkolnikov (shkolnikov@demogr.mpg.de), Head of the Laboratory for Demographic Data.

(C) Copyright is held by the authors.

Working papers of the Max Planck Institute for Demographic Research receive only limited review. Views or opinions expressed in working papers are attributable to the authors and do not necessarily reflect those of the Institute. 
The Transition from School to Work in Russia

During and After Socialism:

Change or Continuity?

\author{
Christoph Bühler*
}

Dirk Konietzka

Rostock, April 11, 2008

* Corresponding author:

Dr. habil. Christoph Bühler

Max Planck Institute for Demographic Research

Konrad Zuse Str. 1

D-18057 Rostock, Germany

Buehler@demogr.mpg.de 


\begin{abstract}
The paper analyzes the influence of institutional change on the transition from school-to-work in Russia. It compares the process of entering working life during socialism (1966-1990) and the transition period (1991-2005) by utilizing information from 6,455 males and females of the "Education and Employment Survey for Russia". The results document influences both of change and of continuity. The introduction of labor markets and a mismatch between qualifications acquired at school and demanded by employers led to increasing risks of unemployment after education and first jobs at the lower levels of the occupational hierarchy. However, as the general character of the educational system and the internal structures of many firms did not change, traditional paths of mobility from educational degrees to particular occupational positions continued to exist. Thus, the transition from school-to-work in Russia did not experience an abrupt change but a gradual adjustment to the new economic order.
\end{abstract}




\section{Introduction}

Entering working life constitutes one of the most important events during the life course. The smoothness of the transition from school-to-work and the first occupational position significantly determine one's occupational career and personal life chances in the immediate and long term (Kerckhoff 1996, 1995). Moreover, entering working life is closely associated with significant events in other life domains, like leaving the parental home, starting marital or non-marital partnerships, or becoming a parent. It is, therefore, a central event in the transition from adolescence to adulthood (Furstenberg et al. 2005, Konietzka and Huinink 2003).

There is a long tradition of research arguing that the pace and the smoothness of the transition from school-to-work are primarily determined by characteristics of the individual person, i.e., his or her educational degree, gender, ethnicity, family background (Becker 1975, Blau and Duncan 1969, Kalter and Kogan 2006, Marsden 1997), or his or her social environment (Coleman 1988, Granovetter 1995). Since the 1980s, however, increasing emphasis is drawn from structural determinants. One key aspect of this structural perspective is the significance of different educational systems and labor markets for the variety of ways of entering working life (see, for example, Müller and Gangl 2004 or Shavit and Müller 1998). Another central aspect addresses social change, i.e. how growing rates of unemployment, the increasing flexibility of labor markets, shifting economic and institutional conditions, or changing forms of educational attainment influence the patterns of starting work (Blossfeld et al. 2005, Müller and Gangl 2004).

Up to now, empirical research on both aspects rests primarily on western societies and especially on Western Europe and the European Union (Gangl 2001, Kerckhoff 2000, Müller and Gangl 2004, Wolbers 2007). However, a growing number of publications also give insight into the structural determinants of the transition from school-to-work in Central and Eastern European countries, like the Czech Republic, Estonia, Hungary, Poland, Russia, or Slovenia (Gerber 2003, Ivancic 2000, Katus et al. 2005, Kogan and Unt 2005, Saar 2005, Simonova and Antonowicz 2006). Addressing the patterns of the transition from school-to-work in former socialist societies is of theoretical and empirical importance. The transition in state socialist countries was characterized by fixed numbers of graduates at different educational levels and pre-set paths into different segments of the employment system. This has changed after the breakdown of socialism. The state disappeared as the central coordinating actor and principles of labor markets were introduced. Entering working life lost its character of a highly regulated and controlled transition and became a process shaped by the supply of and demand for employees (Solga and Konietzka 1999, Walker 2006). Thus, from an empirical point of view, it is of interest to document these develop- 
ments and to integrate them into the different forms of transitions from school-to-work in industrialized societies. The shifting patterns of entering working life are also of theoretical relevance, as they document institutional change in Central and Eastern Europe. They give insights into how much the transition from school-to-work in these countries starts to follow the logic of labor markets or how much socialist traditions persist in leading to path-dependent developments and to a mixture of socialist and capitalistic elements (Nee 1989, Szelényi and Kostello 1996).

In general, Central and Eastern European societies exhibit a variety of paths of transition as they pursue different strategies of institutional change and of introducing market mechanisms (King 2007, 2002, McCann and Schwartz 2006, Stark and Bruszt 1998). Consequently, the transitions from school-to-work differ between these countries (Kogan and Unt 2005). However, the current state of knowledge does not provide sufficient empirical insights into how much these different patterns of entering working life during the transition period are the expression of radical change or how much they represent traditions and legacies of the socialist era. This situation is primarily caused by a lack of data that provide information about the transition from school-towork before and after the breakdown of socialism.

This paper intends to improve the situation by exploring the continuities and changes of the process of entering working life in Russia during the last forty years, i.e. between 1966 and 2005. The analyses concentrate on Russia not only because of the availability of appropriate data but also since it is important to learn more about social developments in this country because of its increasing political and economic significance. Moreover, Russian socialism has a history that is different from other Central and Eastern European countries, as it was the ideal model of state socialism for almost seven decades of the $20^{\text {th }}$ century. "The Soviet Union was, after all, the leading Communist state. "[...] state socialism had a longer life there and was homegrown rather than imposed by a foreign occupying power" (Gerber and Hout 1995, 612).

The paper is structured as follows. In order to analyze comparatively the transition from school-to-work in Russia during the last 40 years, one has to consider that this transition took place in a state socialist environment of central planning and is now taking place within the context of a neoliberal economic order. Thus, a framework is needed that addresses key elements of the institutions involved in the transition from school-to-work in both economic systems. A discussion of the general mechanisms of coordination in market and state socialist economies, their impacts on investment behaviors and on the institutions involved in the process of entering working life will provide this theoretical background (section 2.1). Afterwards, the educational system and the process of entering working life in Russia is characterized (section 2.2). After a short description of the data and variables used in the empirical analyses, results from descriptive and 
multivariate examinations are discussed. The analyses concentrate on three aspects of the transition from school-to-work. The timing of entering the first job, the employment situation after leaving school, and the association between educational degree and first occupational position. Finally, a concluding summary is given.

\section{Entering working life under different economic constitutions}

\subsection{Principles of coordination in markets and redistributive systems}

According to Polanyi (1944), economic systems are organized by three general mechanisms of coordination: reciprocal exchange, markets, and redistribution. As reciprocal exchange characterizes the economic systems of pre-modern societies (Sahlins 1965, Ziegler 1990), markets and redistribution build the two central organizing principles of modern industrialized economies.

Economies that are structured by markets can be described by two ideal types of how societies solve coordination problems within the contexts of industrial relations, education and vocational training, corporate governance, inter-firm relationships, and employment. These two types are liberal markets and coordinated markets (Gallie 2007, 86, Hall and Soskice 2001, 8-9). In liberal market economies, firms act primarily upon competitive market arrangements and - if market-based coordination cannot take place effectively - in hierarchies. Market activities rest on competition and formal contracting as well as on price signals shaping supply and demand. In coordinated markets, firms act upon markets and within hierarchies as well, but these are not the central coordinating institutions. Coordination takes place by relational or incomplete contracting, as well as by the exchange of private information inside networks. Equilibriums are created less by supply and demand than by strategic interaction among firms and other actors (Hall and Soskice 2001, 8). Thus, coordinated market activities take place within business and employer associations, trade unions, networks of cross-shareholding, and legal frameworks that facilitate cooperation among public, administrative, and economic actors (Hall and Soskice 2001, 11).

A redistributive organization of an economy is typified by individuals and organizations that are embedded in bureaucratic relationships of sub- and super-ordination. Overlapping administrative hierarchies and mechanisms of coercion and legal sanctioning replace the coordinating operations of markets (Burawoy and Krotov 1992, Kornai 1984, Litwack 1991). Firms, as the performing economic actors, are located at the bottom of these hierarchies (Ericson 1991). Because the state owns - beside labor - all means of production, administrative and planning institutions directly shape the activities and the character of firms (Grossman 1963, Kornai 1986).

Thus, two institutions are involved in the economic activities of state socialist redistributive systems: the firm as the producing unit and administrative or planning authorities controlling and 
deciding the firm's productive performance, means of production, investments, the number of employees, and the distribution of its output (Adam 1989, Kuczynski 1978, Peng and Heath 1996). However, firms and planning authorities may not act jointly, as the administrative guidelines may contradict the needs of the firm in order to fulfill its production goals or because the plans are incorrectly specified or rest upon outdated information. Administrative authorities have to spend a substantive amount of their resources on coordinative planning in order to ensure that firms can work properly (Grossman 1963). However, firms still face uncertainties with regard to an insufficient supply of materials, technology, and labor (Powell 1977). In order to reduce these uncertainties, they increase their significance and bargaining power within the bureaucracy by expanding the resources under their command, by influencing planning organizations through personal relationships and bargaining, or by establishing informal barter relationships with suppliers (Burawoy and Krotov 1992, Ericson 1984, Litwack 1991, Peng and Heath 1996, Powell 1977, Stark 1992, Svejnar 1991). The strategy of expanding resources under command especially leads to a general culture of hoarding, which is additionally fueled by the fact that firms face only soft budget constraints (Kornai 1980, 27). The outcome is a shortage economy in which enterprises are continually struggling for materials, technology, and labor (Burawoy and Krotov 1992, 19).

\subsection{Investment strategies}

The different institutional frameworks of liberal and coordinated market economies as well as of redistributive systems cause different kinds of investment behavior. In liberal market economies, it is rational to invest in 'switch able assets', as the more flexible and fluid markets give better opportunities to achieve one's investments in different branches and skills (Hall and Soskice 2001). The greater stability of markets in coordinated market economies, however, causes investments in 'specific or co-specific' assets. These two general investment strategies also hold for individual decisions about investments in human capital (Estévez-Abe 2005, Mayer 1997). Individuals are more willing to invest in specific occupational skills - and employers are more willing to take over the responsibility of occupational education - if both expect stable employment relations. This applies to coordinated market economies with their policies of employment protection. Volatile labor markets and short-term profit interests in liberal market economies increase the risks of investments, in particular with regard to occupational skills and it becomes rational for individuals to acquire portable skills, i.e. knowledge and abilities that can be utilized in different occupations and branches (Korpi 2006). Similarly, employers have an incentive only to provide skills that are needed at the particular workplace. 
In redistributive socialist economies, economic actors do not decide about investments, as the resources available for a firm are defined by planning authorities (Rychlewski 1973). Thus, investments are not undertaken according to the demands of an individual firm, but according to the macroeconomic demands of five-year or annual plans. Although the economic activities of state-socialist societies in Central and Eastern Europe were very much characterized by ongoing investments in order to fuel economic growth, the investment decisions reflect more the bureaucratic and political character of the system than economic criteria of efficiency (Littlejohn 1988). Moreover, central planning does not entail any kind of dynamic market developments and hinders any strategic activities of firms, like diversification of products or the introduction of new technologies (Adam 1989). In order to reduce the complexity of plans, it is also meaningful for the planning institutions to favor the creation of large plants with high levels of industrial concentration (Kennedy 1997, Vanhuysse 2007). Thus, the overall economic system is characterized by high stability and, consequently, investments are of a 'specific or co-specific' nature. They are planned in detail and undertaken in particular areas of the economic system in order to support economic growth.

The same logic applies to investments in human capital in state-socialist societies. The educational system is an integral part of the planning activities. Planning authorities have to ensure a sufficient supply of properly educated graduates who will guarantee the planned output of individual firms and who will correspond to the planned future economic developments of the country. Thus, in order to increase the match between educational qualification and skills required at the workplace, the educational system provides pathways of investments in occupational human capital that end in particular occupational positions and spheres of activity (Uunk et al. 2005). To undertake specific investments in human capital is also meaningful for the individual. Occupational qualifications are the key to entering qualified and better-paid entry positions in the employment hierarchy. ${ }^{1}$

\subsection{An institutional perspective of the transition from school-to-work in market economies}

Summarizing the arguments presented in the last section, different forms of economic coordination cause different strategies of investments in human capital. However, educational biographies and the process of entering working life do not only reflect individual decisions. They are also an outcome of opportunities offered by the institutions that are involved in the accumulation

\footnotetext{
${ }^{1}$ However, the demand for a qualified workforce also depends on the organization of work. In the USSR, for example, the production was organized in a highly Tayloristic manner (Connor 1991). Consequently, firms also required employees with only basic education who were willing to work at work places that did not need any kind of occupational qualification.
} 
of human capital and the transition from school-to-work: the educational and the employment system (Gangl 2000). Both systems are closely linked. The character of the educational system determines the quantity and quality of individuals entering the labor market. The employment system has to adapt itself to the qualifications and skills available on these markets, but it is also able to influence the educational system in order to adjust the qualifications of graduates to their demands.

Educational systems differ with respect to their degrees of standardization, stratification, and occupational specialization (Allmendinger 1989, Müller and Shavit 1998). Stratified educational systems select pupils into different educational tracks leading to hierarchically differentiated degrees. In addition, highly vocationally specialized systems provide occupational qualifications and abilities. Less stratified systems have no or only basic selection procedures leading to general educational degrees that are not occupationally differentiated.

Different degrees of stratification and vocational specialization are associated with different types of market-based coordination (Soskice 2005). In liberal market economies, portable skills that can be utilized in different occupations and branches are required. Thus, the educational systems primarily provide general education. In order to adjust these general skills to the specific demands at the work place, employers train graduates internally in job-specific skills. The outcome is a polarized skill structure (Gallie 2007, 88). Due to the lack of a general vocational training system, low-level workers have weakly developed skills. At the same time, however, tertiary education produces highly qualified and mobile professionals.

In coordinated market economies, specific occupational skills can be exploited successfully by the employer and the employee. Correspondingly, educational systems are characterized by a high degree of stratification and selection. Due to the coordinated character of the economy, employers benefit from vocational education provided both by the educational system and carried out by the employers themselves. Intermediate institutions provide firms with information on the quality and content of vocational training (Hall and Soskice 2001, 26) and employers indirectly influence vocational education via employer associations or chambers of industry and commerce. Lower rates of job turnover also make it meaningful to internally educate a labor force that is trained in general occupational skills, as this provides flexible employees who can work at different places in a firm.

The degree of stratification and occupational specialization of the educational system is directly associated with different forms of labor markets for school graduates (Eyraud et al. 1990, 
Gangl 2000, 2001). ${ }^{2}$ Due to the occupational qualifications acquired in the stratified educational systems of coordinated market economies, graduates enter 'occupational labor markets'. Occupational skills and degrees are central criteria for the first job position and subsequent career perspectives. Due to the coordinated relationship between the educational and employment system, the duration of searching for a first job is short, individuals stay longer at their first workplace, and a smaller number of job turnovers characterizes occupational careers (Mayer and Carroll 1987).

Liberal market economies are characterized by 'internal vs. external labor markets'. Here, employers have to take over the task of training their employees according to the requirements of their workplaces. However, given the high rates of job turnover, firms are reluctant to provide general occupational education and instead prefer job-specific training (Mayer 1997). Consequently, internal labor markets emerge. Graduates of lower stratified educational systems - provided with general skills - enter firms at particular entry positions that are defined by general educational levels. Subsequent positions rest on internal career paths, seniority, and the accumulation of firm-specific human capital, as well as on job mobility between employers. In general, entering working life is more difficult and less smooth as in occupational labor markets. There is stronger competition for the entry positions to internal labor markets and there is a higher probability of a mismatch between a graduate's abilities and the requirements of the job. Consequently, graduates entering working life have to search longer for a first job, they are more often confronted with unemployment and temporary jobs, and they move back more often into the educational system.

\subsection{The transition from school-to-work in socialist societies and the USSR}

As already discussed, education was part of the general planning activities in state socialist societies, as the authorities had to ensure that future employees possessed skills and abilities that fit the requirements of the firms, as well as the needs of economic growth. Consequently, the educational systems were centralized, generalized, stratified and vocational (Heynes and Bialecki 1993, Mathews 1982, Meier 1989, Szelenyi and Aschaffenburg 1993). Pupils had to choose particular sides of secondary education that led to particular occupations, which were again located in distinct branches and in distinct positions in the employment hierarchy.

\footnotetext{
${ }^{2}$ See especially Blossfeld (1989), Brauns et al. (1999), Gangl (2001, 2000), Müller and Gangl (2004), Scherer (2004, 2001), Shavit and Müller (1998) for empirical support for the subsequently presented arguments about the associations between types of educational systems and types of labor markets.
} 
In the USSR, the most important selection took place after the eighth-year class, i.e. after attending secondary school for four years and receiving a degree in 'incomplete secondary' education (Gerber and Hout 1995, Titma and Saar 1995). ${ }^{3}$ Pupils were selected into one academic branch or three vocational branches, but a significant number decided to leave school and to enter the employment system without any vocational education. ${ }^{4}$ The academic branch was the continuation of a general secondary education leading to a degree in 'complete secondary' education and offering the opportunity to apply for a place at a university. The three vocational branches were 'Technical-Trade Schools', 'Secondary Technical-Trade Schools', and 'Specialized Secondary Schools'. Courses at Technical-Trade Schools took normally two years and pupils were trained in basic vocational skills without any general education. At Secondary Technical-Trade Schools - which took three years - individuals received both a qualified vocational and a general secondary education. The purpose of these schools was to educate a skilled labor force. Specialized Secondary Schools trained their pupils for the semi-professions in humanities or engineering. These schools could be entered either with an incomplete or complete secondary degree. Higher education took place at universities, academies, and specialized institutes. Courses required an immediate specialization and had an explicit vocational character (Avis 1983).

Although there were some pathways for graduates from vocational and specialized secondary schools into tertiary education, the decision whether and how to continue secondary education was central to an individual's occupational biography (Titma and Saar 1995). This was not only because this step was crucial for the opportunity to enter higher education, but also because pupils entered different spheres of influence. General secondary schools were assigned to the Ministry of Education. Most of the vocational and specialized secondary schools, however, were under the responsibility of industrial ministries. Moreover, graduates from vocational schools had to work for a particular period (up to three years) before they were allowed to reenter the educational system.

Many socialist educational systems had to follow two conflicting philosophies. They were organized along both utilitarian and egalitarian principles (Titma et al. 2003). On the one hand, it was their purpose to supply a properly educated labor force. Following this logic, the schools and universities trained a large number of young people in general knowledge and vocational skills and they selected the most capable ones for higher positions in the administration, the party, or

\footnotetext{
${ }^{3}$ See also Avis (1983), Connor (1991), Mathews (1983, 1982), and O'Dell (1983) for more detailed descriptions of the educational system of the USSR.

${ }^{4}$ However, this number declined continuously in the 1960s and 1970s. In 1965, 42.3\% of the pupils who finished the eighth grade started to work and received their first vocational training on the job (Connors 1991: Table 3.1). In 1975, this share has declined to $2.3 \%$.
} 
research and development. Thus, educational biographies and subsequent occupational positions rested very much on meritocratic aspects. On the other hand, it was also - at least temporarily - a task of the educational systems to reduce social inequality by eliminating the intergenerational inheritance of educational attainment (Gerber and Hout 1995, Heyns and Bialecki 1995). Children from the countryside or from peasant or worker households got preferred access to general secondary and tertiary education in order to receive a representative distribution of all social classes in higher education (Ganzeboom and Nieuwbeerta 1999, Simonová and Antonowicz 2006, Szelényi and Aschaffenburg 1993). The USSR pursued this egalitarian policy during the 1950s, but it gave it up soon in favor of a utilitarian perspective.

Therefore, the general logic of the educational system in the USSR and other state socialist Central and Eastern European societies was not significantly different from that in coordinated market systems. Both rest on standardization, stratification, and occupational specialization (Saar 2005). ${ }^{5}$ Of course, this analogy ends immediately after graduation. Although there are close relationships between the educational and the employment system in coordinated market societies, school graduates have to assert themselves on occupational labor markets. This was obviously not the case during state socialism. The number of graduates from secondary and tertiary education were centrally planned and restricted. The state acted as a central coordinator. Graduates were assigned to particular jobs or they could choose from a limited number of job offers (Gerber and Hout 1995, Titma et al. 2003). These jobs were mostly positions in the occupational hierarchy that corresponded to the educational degree. They were assigned by party-state authorities that used educational attainments and merits as indicators for individuals' abilities and political attitudes (Solga and Konietzka 1999, Titma et al. 2003). Moreover, occupational education often took place in collaboration with local firms and individuals could immediately start to work in these firms after graduation, which was also fueled by the chronic shortage of labor (Katus et al. 2004).

\subsection{The transition from school-to-work in post-socialist societies and Russia}

After the breakdown of the socialist regimes in 1989, and in Russia in 1990, the institutions involved in the transition from school-to-work were exposed by contradictory forces (Nee 1989, Nee and Cao 1999, Poznanski 2001, Stark 1991). On the one hand, all Central and Eastern European countries moved to neo-liberal economic orders by abolishing central planning, creating

\footnotetext{
${ }^{5}$ This applies to the selective character of the educational system. Of course, coordinated market economies and state socialist societies are different according to the degrees of freedom pupils and their parents have in their educational decisions.
} 
markets, liberalizing prices, pursuing a balanced state budget, privatizing state-owned firms, and opening their national economies to foreign trade and investments. On the other hand, institutions, structures, and powerful actors from the times of state socialism did not disappear over night. 'Traditional' institutions and behavioral patterns persisted, leading to path-dependent developments in these countries.

\section{CHANGE}

The rapid move towards a 'capitalism by design' induced significant economic crises in all Central and Eastern European countries, leading to high rates of unemployment, decreasing national products, decreasing wages and wage arrears, or the breakdown of employer-related social security systems. State institutions faced declining budgets and legal insecurities. Thus, schools and universities had to adjust themselves to the new demands of the employment system under difficult circumstances. In general, the educational system kept its character of being selective and of teaching occupational skills. In many cases however, there was only a weak match between the occupational qualifications provided by the school system and the new skills demanded by private or privatized firms or employers in new branches. Firms started to train their employees internally and most educational systems - with the exception of Slovenia (Feldmann 2006) moved towards a less selective structure by teaching general knowledge and skills (King 2007).

Economic crises induced a significant reduction of open positions for school graduates resulting in high rates of youth unemployment. In 1993, for example, around 47\% of the population in Bulgaria - aged 15 to 24 - were unemployed and in Poland it applied to $32 \%$ in the same age range. In Russia, however, levels of youth unemployment were relatively low, i.e. about $13 \%$ in 1993, but increased continuously up to a level of $27 \%$ in 1998 (UNICEF 2007). Furthermore, the institutional framework of the transition from school-to-work changed significantly. The state disappeared as the central coordinator and market mechanisms were introduced. Graduates had to face the new situation by searching for open positions and competing with others for vacancies (Walker 2006). Firms also started to hire graduates according to their potential productivity. Thus, educational degrees lost their character of status features and became indicators of individuals' abilities.

Although high rates of unemployment, as well as continuing economic and social problems, gave rise to backward-oriented political forces opposing the reforming governments (Vanhuysse 2007), most of the Central and Eastern European countries moved towards market-based economic systems (Stark and Bruszt 1998). However, there are different interpretations as to which kind of market coordination these countries moved. One key-argument of the theory of the Varie- 
ties of Capitalism is that a workforce with high occupational qualifications is able to create strong unions that push an economic system towards coordinated markets (King 2007). The educational systems in Central and Eastern Europe continued to supply the labor markets with occupationally skilled graduates, but at the same time the workforce lost its power because of the dissolution of socialist workers' organizations, the break down of traditional industries, privatization, restructuring and tertiarization, declining numbers of jobs and an insufficiently qualified workforce (Bole and Greskovits 2006, Vanhuysse 2007). Furthermore, coordinated markets need some degree of trustworthiness in its institutions, as well as a common understanding of the roles and interests of the participating economic and political actors (Hall and Soskice 2001, 63). The rapid transition from a state socialist order towards a neo-liberal economic system weakens these understandings and perceptions of trustworthiness. Structures of liberal markets coordination are easier to establish and, consequently, elements of this kind of coordination predominate - with the exception of Slovenia - in Central and Eastern European countries (Feldmann 2006, 851).

In general, the emerging mixture of elements from state socialism, liberal and coordinated markets can be summarized by the terms 'liberal dependent systems' and 'patrimonial systems' (King 2007, 316). The coordination in liberal dependent systems - like in the Czech Republic, Poland, or Hungary - is organized according to the principles of liberal markets, but multinational companies, foreign direct investments, and exports characterize the economic systems. Patrimonial systems - as they are present in Russia or the Ukraine - rest on patron-client relationships on all levels of the political, economic, and administrative sphere. This situation is an outcome of the harsh introduction of neoliberal capitalism and mass privatization from above, which had to be met by institutions that were only insufficiently prepared for the new situation. The subsequent breakdown of the economy and of parts of state institutions gave rise to the establishment of informal structures that rest on personal relationships of power, loyalty, and exchange. Fueled by wage arrears, paternalistic relationships between employers and employees emerged where employers distribute consumer goods and aid employees in gaining access to means of subsistence (King 2007, 320).

\section{CONTINUITY}

Although the countries of Central and Eastern Europe moved quickly to neo-liberal economic orders, they made only insufficient effort in adjusting their institutions - like public administrations, legal regulations, markets, or educational systems - to the new economic framework (McCann and Schwartz 2006, 1341). However, these developments are not only the expression of insufficient institutional designs. Institutions and their activities also have to be socially 
legitimized. Legitimizing forces rest on long-term cultural developments and, consequently, they are highly inert. They started to change only slowly after the breakdown of state-socialism (Nee and Cao 2002). Firms act on habitualized and legitimizing traditions as well. Thus, many formerly socialist employers proceeded only gradually towards a capitalistic organization of the firm, thereby creating a great variety of combinations of capitalistic and socialist elements (Soulsby and Clark 2006). Socialist traditions also continued to be present because the privatization of state-owned firms took place with different intensities and strategies in Central and Eastern European countries (Stark and Bruszt 1998). Within this process, the state remained as a significant actor making strategic choices regarding privatization, monetary policy, the liberalization of markets, or on its own influence and position in a future market-based economy (King 2007, Feldmann 2006).

All these aspects were present in Russia during the transition period, but there were also specific developments in the country that supported the continuation of socialist traditions (Clarke 2004). Due to the harsh and uncoordinated introduction of a neo-liberal economic order, a real privatization of large parts of enterprises failed, with the outcome that the Russian economy became dominated by enterprises of mixed, i.e. state and private, ownership (Lane 2000). Thus, the state remained as a central economic actor, employer, and controlling entity. In the 1990s, the Russian economy was also characterized by the export of raw materials and military goods. Monopolistic firms, which were instrumentalized by the state, dominated these markets. Other firms produced primarily for local markets and there was a low engagement of foreign investors due to substantive legal insecurities. Thus, many Russian firms neither had to compete with other firms on international markets nor did they face foreign competitors on their local markets. Moreover, gaps in legal formulations created, to some extent, a 'soft budget' situation. Bankrupt firms were able to continue their work because of barter and increasing debts. Due to low wages, but high political and economic costs of dismissal and unemployment, firms were attracted to keeping their traditional organizational structure with its high levels of employees. Altogether, these aspects set many managers under barely any pressure to reorganize their corporations. The circumstances allowed them opportunities to keep the character of Russian firms as units of production but not as profit-making companies. This situation changed after 1998. New legal regulations forced firms to reorganize in a capitalistic manner and to give more security to foreign investors. Bankrupt firms had to be closed, were bought by other companies, or were integrated into holding structures (Clarke 2004). However, substantial economic and social problems remained supporting the patron-client system of personal relationships, dependence, and enforced loyalty. 
Thus, although the formal economic order changed significantly in Russia, the institutions involved became only partly adjusted to the new circumstances and many firms continued to function as they did during socialist times. Persistence characterized also the educational system (Elliott and Tudge 2007, Grigorenko 1999). It became open to private schools and universities, new branches of education were founded, all branches of education became unified under the Ministry of Education, and firms disappeared as local mentors for schools, but the overall selective and occupational character of education did not change. However, many schools were not able to follow the new developments. In the 1990s, many vocational schools or industry-related training institutions trained young people for jobs that did not exist any more or that were associated with factories that were soon closed.

\section{GENERAL STRUCTURE OF ANALYSES}

Altogether, the contradictory forces of change and continuity make it difficult to specify hypotheses about the changing character of the transition from school-to-work after the breakdown of socialism in Russia. In general, it has to be hypothesized that this process has changed. The quantity and quality of educational degrees are not centrally planned any more, the state has disappeared as the central coordinator, and firms are not obliged to hire particular numbers of graduates set in advance. Thus, one has to hypothesize that the smoothness of the transition from school-to-work has declined. As graduates have to search for open positions and as they are confronted with the competitive situation of labor markets, the process of entering working life takes longer and they are more often confronted with periods of unemployment. Moreover, as employers have started to handle educational degrees as indicators of human capital and personal productivity and less as status features, traditional channels from particular educational degrees into particular occupational positions have disappeared.

However, how significant are these expected changes? Here, no clear hypotheses can be formulated. The discussion in the last two sections has shown that heterogeneous and contradictory forces are present in the changing process of entering working life. Therefore, the subsequent empirical analyses will primarily explore the transition from school-to-work in Russia and the changes that occurred during socialism and the transition period. They will draw special emphasis on the question of how significantly the process of entering working life has changed since the breakdown of state socialism and how much developments that already started in the Soviet period continued to exist. 


\section{Data and Variables}

\subsection{The Education and Employment Survey for Russia}

The subsequent empirical analyses utilize data from the 'Education and Employment Survey for Russia' (EES). The survey was carried out by the Max Planck Institute for Demographic Research in Rostock, Germany, in collaboration with the Independent Institute for Social Policy in Moscow. The purpose of the EES was to collect retrospective information on the migration, education, and employment biographies of the Russian population. It, therefore, addresses episodes of full-time and part-time education, employment, unemployment, parental leave, military service, and non-employment. It draws special emphasis on parallel activities like the combination of education and employment or first and second jobs. ${ }^{6}$

The sample of individuals interviewed for the EES consists of a sub-population of respondents who participated in the first wave of the 'Russian Generations and Gender Survey' (GGS). ${ }^{7}$ The first wave of the Russian GGS was carried out in 2004 and addressed individuals aged 18 to 79. The EES took place in 2005 and covered all respondents of the first wave of the Russian GGS aged 18 to 55. This age-related limitation took place because it was one purpose of the EES to collect biographical information that helps to explain demographic events during the first half of life, like leaving the parental home, partnership formation, or fertility. Altogether, $84 \%$ of the target population was interviewed, thereby providing information from 6,455 individuals, i.e. from 3,995 women and 2,460 men. ${ }^{8}$

\subsection{Variables used in the analyses}

\section{EVENTS AND VARIABLES CHARACTERIZING THE TRANSITION FROM SCHOOL-TO-WORK}

The analyses will explore the process of entering working life with the help of three aspects: the timing of the transition from school-to-work, the employment situation after finishing school or university, and the degree to which graduates enter first occupational positions that correspond to their educational qualifications.

The timing of the transition from school-to-work will be addressed by a respondent's age at the moment of leaving school and the moment of entering working life, as well as by the period

\footnotetext{
${ }^{6}$ The survey instruments of the EES are documented by Bühler et al. (2007).

${ }^{7}$ See Vikat et al. (2007) and 'www.unece.org/pau/ggp/Welcome.html' for more information about the Generations and Gender Surveys.

${ }^{8}$ Utilizing the population of respondents of the GGS, the EES has to handle one shortcoming of this survey: the inhabitants of Moscow and St. Petersburg are significantly underrepresented in the sample of the first wave of the GGS. However, comparisons between results from the EES and official statistics of Russia show that the EES provides information that is representative for the whole Russian Population (Soroko und Konietzka 2006). Thus, the subsequent analyses will not be separated for respondents from Moscow or St. Petersburg and the rest of the country, but the multivariate analyses will control for these two cities.
} 
between these two events. A respondent left the educational system, if he or she has ended an educational period - irrespective of whether he or she has formally graduated - and if he or she did not start a new or continued a former education as the subsequent major activity. Working life was entered if dependent or self-employed work became for the first time in his or her life the major activity and if this activity lasted for at least three months. ${ }^{9}$

Following a general design of collecting retrospectively individual information, the EES started to gather biographical events from January 1 of the year in which a respondent turned 17. For some respondents, however, this design does not cover their period of entering working life because they had already left school at the age of 15 or 16 . This applies to 590 individuals. Additional information from the GGS shows that most of these respondents left the educational system after an incomplete secondary education. Consequently, the date of finishing school could be reconstructed for these individuals. However, no additional information is available that allows for the imputation of the missing dates of entering working life. Thus, this group of respondents has to be excluded from the analyses and the subsequent results provide evidence only for respondents who were in the educational system on January 1 of the year when they turned 17. This includes all individuals who were in any kind of vocational or academic secondary education or who participated in a professional training at that time.

A respondent's employment situation after leaving the educational system is covered by five alternatives: he or she started immediately to work, became unemployed, stayed at home or was a homemaker, was called up for military service (males only), or faced another situation. ${ }^{10}$ Special emphasis was drawn to address periods of unemployment. This is defined by the situation in which a respondent 'had no work and was looking for a job'.

Finally, a respondent's first occupational status is represented by the occupational position of his or her first job. The occupational position was measured by a variable that directly addresses the different levels of blue- and white-collar work, as well as of self-employment in the occupational hierarchy. According to blue-collar positions, the variable focuses on agricultural workers, unqualified, qualified, and highly qualified workers. The latter category also includes team-leaders and foremen. White-collar positions are covered by employees performing simple or complex tasks, as well as by professionals who either perform autonomously important tasks or have significant managerial responsibilities. Finally, the category self-employed represents all respondents who run their own businesses or who work as free-lancers.

\footnotetext{
${ }^{9}$ The period of three months follows the general design of the EES that considers only episodes of a minimum length of a quarter of a year.

${ }^{10}$ Female respondents on maternity or parental leave are defined as graduates who started immediately to work, as this situation requires an employment relationship.
} 
Table 1:

Definition of cohorts

\begin{tabular}{ll}
\hline Period & Historical context \\
\hline $1966-1970$ & Brezhnev \\
$1971-1975$ & Brezhnev \\
$1976-1979$ & baby boomers \\
$1980-1984$ & 'stagnation' \\
$1985-1990$ & Glasnost and Perestroika \\
$1991-1999$ & transition crises \\
$2000-2005$ & recovery \\
\hline
\end{tabular}

\section{EXPLANATORY VARIABLES}

In the multivariate analyses, two groups of variables build the central explanatory factors: a respondents' educational degree and the period in which he or she has left school or in which he or she has entered working life. The educational degree was measured by the kind of education the respondent received before he or she left school or university. The variable addresses various forms of educational attainment: complete secondary education, Technical-Trade Schools, fulltime professional training, Secondary Technical-Trade Schools, Specialized Secondary Schools, tertiary education, and other forms of education. The first category covers all respondents who have received a degree in complete secondary education, but who were not able or willing to enter a university. Thus, these individuals started to work without any occupational training.

The periods in which the respondents left school and in which they started to work are represented by two variables: the cohort of leaving school and the cohort of entering working life. The cohorts addressing Russia's socialist era are defined in accordance with particular political periods (see Table 1). The transition period is divided into two parts. The period 1991 to $1999 \mathrm{ad}-$ dresses Russia's substantive economic and social crises. The years 2000 to 2005 cover the beginning of the economic recovery of the country. Both cohorts have their shortcomings, because the timing of the events of leaving school and of entering working life is not completely exogenously given. They are to some extent influenced by the individuals. This holds especially true for the transition period, where uncertain labor market conditions, declining incomes, and high rates of unemployment motivated young adults to extend their stay in the educational system.

The multivariate analyses consider additional covariates for purposes of control. Two variables address a respondent's place of living in the period when he or she left school or university and when he or she entered working life. The categories of these variables are rural area, town or city, or regional, territorial, or republican center. To control for a possible bias due to the underrepresented population in Moscow and St. Petersburg, one variable addresses whether the respondent lived in one of these two cities at the time he or she participated in the first wave of the GGS. Finally, the analyses estimating the determinants of the first occupational position consider 
different episodes of non-employment between the period of leaving home and the period of entering working life. For female respondents, these episodes are unemployment, maternity leave, and staying at home as a housewife. The analyses for male respondents address episodes of unemployment and military service.

\section{Empirical results}

The empirical results are presented in two steps. Firstly, we describe the developments of various variables characterizing the transition from school-to-work between 1966 and 2005. These are the distributions of educational degrees, the timing of entering working life, the employment situation after leaving school, and the distribution of the first occupational positions. Secondly, results from multivariate analyses demonstrate the determinants of the timing of entering work, the employment situation after leaving the educational system, and the occupational position of the first job.

\subsection{Educational degree}

Table 2 reports the distributions of the respondents' educational degrees, separated by gender and the cohort of leaving school or university. Both for men and women, the results identify common developments. On the one hand, it was a general educational policy of the Soviet Union to improve the vocational qualifications of young adults. This policy is observable by the decreasing shares of individuals who entered working life with no occupational or only a basic vocational education, as well as by increasing numbers of graduates from Secondary Technical-Trade Schools and Specialized Secondary Schools. On the other hand, universities expanded in the 1960s and 1970s, but afterwards their sizes were kept constant, as the system started to produce too many university graduates. The results also demonstrate that women in the USSR tended to be on average better educated than men (Ganzeboom and Nieuwbeerta 1999). This holds especially true for Secondary Specialized Colleges, where white-collar professions were taught, compared to Technical-Trade Schools and Secondary Technical-Trade Schools that were characterized by blue-collar, male-dominated professions. After the breakdown of socialism, women continued to be better educated than men. Moreover, a strong move towards tertiary education is observable. After 1999, the number of female and male graduates with a degree from a secondary vocational school declined significantly and $40.4 \%$ of the female and $36.1 \%$ of the male respondents leaving the educational system during that period graduated from a university. 
Table 2

Distributions of educational degrees, separated by cohorts of leaving school or university

A. Females

\begin{tabular}{lccccccc}
\hline & \multicolumn{7}{c}{ Cohorts of leaving school or university } \\
\hline & $1966-$ & $1971-$ & $1976-$ & $1980-$ & $1985-$ & $1991-$ & $2000-$ \\
& 1970 & 1975 & 1979 & 1984 & 1990 & 1999 & 2005 \\
\hline $\begin{array}{l}\text { Complete secondary } \\
\text { education }\end{array}$ & 50.5 & 33.4 & 28.9 & 22.3 & 19.4 & 17.7 & 12.8 \\
$\begin{array}{l}\text { Technical-Trade } \\
\text { School }\end{array}$ & 13.5 & 9.9 & 7.3 & 8.9 & 5.9 & 5.4 & 2.9 \\
$\begin{array}{l}\text { Full-time professional } \\
\text { training }\end{array}$ & 4.2 & 3.8 & 3.0 & 2.9 & 2.4 & 2.4 & 0.3 \\
$\begin{array}{l}\text { Secondary Technical- } \\
\begin{array}{l}\text { Trade School } \\
\text { Specialized Secondary }\end{array}\end{array}$ & 9.0 & 11.5 & 15.5 & 17.3 & 16.6 & 17.7 & 11.5 \\
$\begin{array}{l}\text { School } \\
\text { Tertiary education }\end{array}$ & 18.3 & 30.0 & 31.7 & 33.8 & 36.0 & 35.5 & 30.8 \\
Other education & 1.0 & 9.7 & 11.5 & 13.8 & 18.6 & 19.4 & 40.4 \\
\hline Total & 100 & 100.1 & 100.1 & 100.0 & 100.1 & 100.1 & 100.0 \\
\hline $\mathrm{N}$ & 311 & 506 & 505 & 485 & 592 & 685 & 312 \\
\hline
\end{tabular}

Source: EES, own calculations

B. Males

\begin{tabular}{lccccccc}
\hline & \multicolumn{7}{c}{ Cohorts of leaving school or university } \\
\cline { 2 - 8 } & $\begin{array}{c}1966- \\
1970\end{array}$ & $1971-$ & $1976-$ & $1980-$ & $1985-$ & $1991-$ & $2000-$ \\
& 44.0 & 34.8 & 35.3 & 20.7 & 20.2 & 14.7 & 12.0 \\
\hline $\begin{array}{l}\text { Complete secondary } \\
\text { education }\end{array}$ & 17.0 & 16.3 & 13.7 & 11.5 & 9.4 & 9.8 & 5.8 \\
$\begin{array}{l}\text { Technical-Trade } \\
\text { School }\end{array}$ & & & & & & & \\
$\begin{array}{l}\text { Full-time professional } \\
\text { training }\end{array}$ & 2.5 & 5.8 & 3.6 & 4.1 & 3.9 & 3.6 & 1.6 \\
$\begin{array}{l}\text { Secondary Technical- } \\
\text { Trade School }\end{array}$ & 20.8 & 15.2 & 20.0 & 26.4 & 26.5 & 25.6 & 22.9 \\
$\begin{array}{l}\text { Specialized Secondary } \\
\text { School }\end{array}$ & 7.6 & 16.7 & 15.7 & 20.0 & 20.7 & 25.6 & 20.2 \\
$\begin{array}{l}\text { Tertiary education } \\
\text { Other education }\end{array}$ & 1.3 & 6.5 & 10.8 & 13.6 & 16.6 & 18.4 & 36.1 \\
\hline Total & 6.9 & 4.7 & 1.2 & 3.7 & 2.8 & 2.3 & 1.6 \\
\hline $\mathrm{N}$ & 100.1 & 100.0 & 100.3 & 100.0 & 100.1 & 100.0 & 100.2 \\
\hline Source: EES, own calculations & 159 & 276 & 249 & 295 & 362 & 441 & 258 \\
\hline
\end{tabular}

Finally, a special characteristic of the Soviet employment system has to be observed: the high shares of academically qualified individuals who started their first jobs without an occupational education. There were many more graduates from academic secondary schools than open places at universities. Due to this bottleneck situation, many young people had to enter the work force without any formal vocational training. This share of individuals decreased continuously during socialism, but it is remarkable that it did not decline sharply after the breakdown of the socialist system. 
Table 3

Percentiles of the age at leaving school or university, separated by gender and cohort of leaving school or university

(Kaplan-Meier estimates)

\begin{tabular}{lcccccccc}
\hline Cohort of leaving school or & \multicolumn{4}{c}{ Females } & \multicolumn{4}{c}{ Males } \\
\cline { 2 - 8 } university & $\mathrm{p}_{0.25}$ & $p_{0.50}$ & $\mathrm{p}_{0.75}$ & $\mathrm{~N}$ & $\mathrm{p}_{0.25}$ & $p_{0.50}$ & $\mathrm{p}_{0.75}$ & $\mathrm{~N}$ \\
\hline $1966-1970$ & 17.0 & 17.4 & 18.2 & 312 & 16.9 & 17.3 & 17.7 & 162 \\
$1971-1975$ & 17.2 & 18.1 & 18.1 & 508 & 17.2 & 17.7 & 18.4 & 276 \\
$1976-1979$ & 17.4 & 18.3 & 19.3 & 508 & 17.2 & 17.7 & 18.6 & 251 \\
$1980-1984$ & 17.5 & 18.6 & 19.7 & 489 & 17.6 & 18.2 & 19.0 & 302 \\
$1985-1990$ & 17.6 & 18.4 & 19.6 & 595 & 17.4 & 18.1 & 18.9 & 367 \\
$1991-1999$ & 17.6 & 18.7 & 20.0 & 687 & 17.5 & 18.3 & 19.2 & 445 \\
$2000-2005$ & 18.9 & 20.5 & 22.3 & 435 & 18.4 & 20.2 & 22.3 & 351 \\
\hline Total & 17.4 & 18.5 & 19.7 & 3,534 & 17.4 & 18.2 & 19.2 & 2,154 \\
\hline
\end{tabular}

Source: EES, own calculations

Note: Number of censored cases in the youngest cohort of leaving school (2000-2005): females: 121 (27.8\%), males: $92(26.2 \%)$.

\subsection{The timing of leaving school and of entering working life}

One basic characteristic of the transition from school-to-work is an individual's age at which he or she is leaving the educational system and his or her age at entering working life. Table 3 and Table 4 report the respondents' estimated percentile ages at the occurrence of these events. Looking at the respondents who have spent all of their time in the educational system during socialism, i.e. the cohorts that left school by 1990, the results document a median age of females and males of around 18 years (see Table 3). Women's median age, moreover, shows a continuous increase for one year between the cohort 1966-1970 and 1985-1990. Surprisingly, there is no major change of this pattern for the cohort leaving the educational system during the first period of transition between 1991 and 1999. Educational decisions made during socialism, as well as the continued existence of the traditional educational system, might be responsible for this result. Only the youngest cohort shows a significant change. Consistent with the high shares of univer-

Table 4

Percentiles of the age at entering working life, separated by gender and cohort of leaving school or university

(Kaplan-Meier estimates)

\begin{tabular}{lcccccccc}
\hline \multirow{2}{*}{$\begin{array}{l}\text { Cohort of leaving school or } \\
\text { university }\end{array}$} & \multicolumn{4}{c}{ Females } & \multicolumn{4}{c}{ Males } \\
\cline { 2 - 8 } & $\mathrm{p}_{0.25}$ & $p_{0.50}$ & $\mathrm{p}_{0.75}$ & $\mathrm{~N}$ & $\mathrm{p}_{0.25}$ & $p_{0.50}$ & $\mathrm{p}_{0.75}$ & $\mathrm{~N}$ \\
\hline $1966-1970$ & 17.4 & 17.9 & 18.7 & 310 & 17.2 & 17.6 & 19.0 & 162 \\
$1971-1975$ & 17.5 & 18.4 & 19.7 & 506 & 17.4 & 18.2 & 20.5 & 275 \\
$1976-1979$ & 17.7 & 18.6 & 19.7 & 501 & 17.3 & 18.3 & 20.6 & 246 \\
$1980-1984$ & 18.0 & 18.9 & 20.2 & 487 & 17.9 & 19.5 & 21.3 & 300 \\
$1985-1990$ & 18.0 & 18.8 & 20.5 & 587 & 17.9 & 20.3 & 21.3 & 364 \\
$1991-1999$ & 18.5 & 19.7 & 22.1 & 680 & 18.3 & 20.1 & 21.2 & 443 \\
$2000-2005$ & 19.3 & 21.2 & 22.7 & 313 & 19.0 & 20.6 & 22.3 & 259 \\
\hline Total & 17.9 & 19.0 & 20.6 & 3,384 & 17.7 & 19.5 & 21.2 & 2,049 \\
\hline
\end{tabular}

Source: EES, own calculations

Note: Number of censored cases in the youngest cohort of leaving school (2000-2005): females: 81 (25.9\%), males: $47(18.1 \%)$. 
Table 5

Percentiles of months between leaving school and entering working life, separated by gender and cohort of leaving school or university

(Kaplan-Meier estimates)

\begin{tabular}{lcccccccc}
\hline Cohort of leaving school or & \multicolumn{4}{c}{ Females } & \multicolumn{5}{c}{ Males } \\
\cline { 2 - 9 } university & $\mathrm{p}_{0.25}$ & $p_{0.50}$ & $\mathrm{p}_{0.75}$ & $\mathrm{~N}$ & $\mathrm{p}_{0.25}$ & $p_{0.50}$ & $\mathrm{p}_{0.75}$ & $\mathrm{~N}$ \\
\hline $1966-1970$ & 1.0 & 2.0 & 4.0 & 309 & 0.5 & 2.0 & 8.0 & 162 \\
$1971-1975$ & 1.0 & 2.0 & 3.0 & 504 & 1.0 & 2.0 & 25.0 & 276 \\
$1976-1979$ & 1.0 & 1.0 & 3.0 & 500 & 1.0 & 2.0 & 25.0 & 246 \\
$1980-1984$ & 1.0 & 2.0 & 3.0 & 487 & 1.0 & 2.0 & 27.0 & 300 \\
$1985-1990$ & 1.0 & 2.0 & 3.0 & 586 & 1.0 & 3.0 & 28.9 & 364 \\
$1991-1999$ & 1.0 & 3.0 & 20.1 & 679 & 1.0 & 4.9 & 28.0 & 443 \\
$2000-2005$ & 2.0 & 3.0 & 21.9 & 312 & 1.0 & 3.0 & 25.0 & 358 \\
\hline Total & 1.0 & 2.0 & 4.0 & 3,377 & 1.0 & 2.0 & 27.0 & 2,049 \\
\hline
\end{tabular}

Source: EES, own calculations

sity graduates during that period, the median ages for females and males increased for around two years, compared to the respondents who graduated between 1991 and 1999.

According to male's median age at the time of entering working life, a continuous increase has to be observed (see Table 4). Half of the male respondents from the oldest cohort started to work at an age of 17.6. However, $50 \%$ of the cohort that graduated in the second half of the $1980 \mathrm{~s}$ started their first job at an age of 20.3. This can be explained by an increasing share of male respondents called up for military service. Women document a less pronounced development, as their median age increased for around one year during the period of socialism. Unexpectedly again, men did not start to enter working life at higher ages during the first period of transition. This can be interpreted as an indicator that, for men, traditional channels of entering working life continued to exist. However, this does not hold for females. Here, the median age at entering working life increased for around one year compared to the cohort of graduates from 1985 to 1990. This pattern continued to exist for the youngest cohorts. At the beginning of the new century, females entered working life at much higher ages than they did in the 1990s, as the median age grew for around 1.5 years. Male's median age, however, increased only slightly for around half a year.

Finally, Table 5 reports the estimated percentiles of the length of the period between leaving the educational system and starting work. Due to the planned character of the transition from school-to-work and the chronic shortage of labor during state socialism, the majority of female and male graduates moved directly into the employment system. The median duration of two months is primarily an expression of the fact that schools and universities finished in June and that work typically started in September. Most women entered their first job within a short period after graduation. Among all women who finished school or university between 1975 and 1990, $75 \%$ entered working life within three months. This was not the case for men, as many of them 
were drafted for military service after finishing education, thereby postponing their start of work for at least two years. ${ }^{11}$

For the cohorts that have left school since the breakdown of socialism, the results show a polarized development. On the one hand, the median duration increased only slightly for both females and males. Thus, although the Russian economy had to face a serious economic crisis during its transition, the majority of graduates entered working life within a period of three to five months. On the other hand, there was an increasing share of females and males facing long periods between leaving school and entering working life. For example, 25\% of all women who graduated between 1991 and 1999 reported a period of at least 20 months. Among male respondents, however, the share of individuals experiencing very long periods between the end of school and the start of work decreased, which was caused by a declining number of graduates called up for military service.

\subsection{Employment situation after leaving school or university}

Table 6 documents the employment situations of the respondents after leaving school, i.e. whether they entered directly the employment system or whether they became unemployed, were drafted for military service, or stayed at home. The results show different developments for females and males. Between 1966 and 1980, the share of women who entered the employment system directly increased continuously. At the same time, the share of women who attributed themselves as being unemployed after graduation decreased. It is remarkable, however, that a respondent was unemployed at all during that time. Unemployment was officially nonexistent and there was a chronic shortage of labor. However, the EES addressed the status of unemployment by the situation that the respondent had no work and was looking for a job. Thus, unemployment was probably primarily associated with a search process and of not having a job right after graduation.

The employment situation of males documents a different development. Here, the share of respondents entering working life directly decreased continuously during socialism. This was primarily caused by the fact that more and more graduates were drafted for military service. However, this trend was not primarily caused by changing politics related to conscription. It rests more on the fact that males stayed longer in the educational system, graduated at higher ages, and, thus, were more often drafted immediately after finishing school.

During the transition period, the employment situations of women and men moved into different directions. A significantly smaller share of women entered working life directly. Among all women who graduated in the period of Perestroika, $81.7 \%$ started to work immediately. However,

\footnotetext{
${ }^{11}$ Military service took two years in the land forces and three years in the navy.
} 
Table 6

Distributions of employment situation after leaving school or university, separated by gender and cohort of leaving school or university

A. Females

\begin{tabular}{lccccccc}
\hline & \multicolumn{7}{c}{ Cohort of leaving school or university } \\
& $1966-$ & $1971-$ & $1976-$ & $1980-$ & $1985-$ & $1991-$ & $2000-$ \\
& 1970 & 1975 & 1979 & 1984 & 1990 & 1999 & 2005 \\
\hline Working & 73.4 & 80.3 & 82.7 & 84.8 & 81.7 & 61.3 & 57.8 \\
Staying at home, & 10.9 & 7.9 & 9.8 & 8.2 & 10.8 & 21.1 & 20.2 \\
housewife & & & & & & & \\
Unemployed & 7.4 & 6.9 & 4.3 & 2.9 & 2.7 & 10.6 & 14.6 \\
Other situation & 8.3 & 4.9 & 3.2 & 4.1 & 4.9 & 7.0 & 7.3 \\
\hline Total & 100.0 & 100.0 & 100.0 & 100.1 & 100.1 & 100.0 & 99.9 \\
\hline $\mathrm{N}$ & 312 & 508 & 508 & 488 & 595 & 688 & 287 \\
\hline
\end{tabular}

B. Males

\begin{tabular}{lccccccc}
\hline & \multicolumn{7}{c}{ Cohort of leaving school or university } \\
& $1966-$ & $1971-$ & $1976-$ & $1980-$ & $1985-$ & $1991-$ & $2000-$ \\
& 1970 & 1975 & 1979 & 1984 & 1990 & 1999 & 2005 \\
\hline Working & 71.0 & 65.7 & 69.3 & 58.6 & 51.0 & 48.1 & 59.4 \\
Staying at home & 3.1 & 4.0 & 5.2 & 1.3 & 3.5 & 3.8 & 4.2 \\
Unemployed & 7.4 & 7.2 & 6.4 & 3.6 & 7.6 & 14.6 & 14.2 \\
Military service & 11.1 & 18.1 & 12.0 & 28.2 & 30.3 & 24.3 & 12.1 \\
Other situation & 7.4 & 5.1 & 7.2 & 8.3 & 7.6 & 9.2 & 10.0 \\
\hline Total & 100.0 & 100.1 & 100.1 & 100.0 & 100.0 & 100.0 & 99.9 \\
\hline $\mathrm{N}$ & 162 & 277 & 251 & 302 & 367 & 445 & 239 \\
\hline
\end{tabular}

Source: EES, own calculations

this share declined to a level of $61.3 \%$ during the first period of transition and declined further to $57.3 \%$ between 2000 and spring 2005. Consequently, the number of women staying at home or being unemployed rose sharply. Especially the high share of women describing themselves as housewives is remarkable. Most Russian households faced a serious decline of their incomes during the 1990s and only a minority of them could afford that household members deliberately not engage in income-generating activities. Thus, we assume that many of these women were de facto unemployed, but did not perceive their situation as unemployment. However, there is also the possibility that a substantial number of these women started to follow - deliberately or forced - traditional gender roles.

Although the share of male respondents who described themselves as being unemployed doubled between the period of Perestroika and the first phase of the transition period in the 1990s, the share of graduates entering working life directly declined only slightly. Moreover, it increased substantially at the beginning of the new century. This contradictory development was possible because of the declining number of males that were drafted for military service. Conscription continued to be mandatory, but many ways developed to avoid it. Thus, the share of respondents who were drafted immediately after finishing school or university declined from $24.3 \%$ in the 1990s to $12.1 \%$ between 2000 and spring 2005 . 
Table 7

Distributions of first occupational position, separated by gender and cohort of entering working life

A. Females

\begin{tabular}{lccccccc}
\hline & \multicolumn{7}{c}{ Cohort of entering working life } \\
\hline & $1966-$ & $1971-$ & $1976-$ & $1980-$ & $1985-$ & $1991-$ & $2000-$ \\
& 1970 & 1975 & 1979 & 1984 & 1990 & 1999 & 2005 \\
\hline Blue-collar positions & & & & & & & \\
$\quad$ Agricultural & 0.4 & 2.2 & 0.8 & 1.8 & 0.9 & 1.0 & 0.3 \\
$\quad$ Unqualified & 23.9 & 11.4 & 9.9 & 10.7 & 8.2 & 10.6 & 8.6 \\
$\quad$ Qualified & 25.7 & 22.1 & 23.7 & 19.0 & 17.6 & 10.6 & 7.3 \\
$\quad$ Highly qualified & 2.9 & 6.9 & 5.7 & 4.4 & 4.1 & 2.3 & 1.6 \\
$\quad$ Total share of blue- & 52.9 & 42.6 & 40.1 & 35.9 & 30.8 & 24.5 & 17.8 \\
$\quad$ collar positions & & & & & & & \\
$\quad$ White-collar positions & & & & & & & \\
$\quad$ Simple tasks & 23.9 & 19.1 & 20.2 & 22.8 & 20.3 & 28.5 & 34.4 \\
$\quad$ Qualified tasks & 17.0 & 23.6 & 25.3 & 25.0 & 29.5 & 27.7 & 30.9 \\
$\quad$ Professional & 6.2 & 14.8 & 14.2 & 16.2 & 19.2 & 18.7 & 16.3 \\
$\quad$ Total share of white- & 47.1 & 57.5 & 59.7 & 64.0 & 69.0 & 74.9 & 81.6 \\
$\quad$ collar positions & & & & & & & \\
Self-employed & 0.0 & 0.0 & 0.2 & 0.0 & 0.4 & 0.6 & 0.6 \\
\hline$\quad$ Total & 100.0 & 100.1 & 100.0 & 99.9 & 100.2 & 100.0 & 100.0 \\
\hline $\mathrm{N}$ & 276 & 508 & 494 & 496 & 562 & 621 & 314 \\
\hline Sol & & & & & &
\end{tabular}

Source: EES, own calculations

B. Males

\begin{tabular}{|c|c|c|c|c|c|c|c|}
\hline & \multicolumn{7}{|c|}{ Cohort of entering working life } \\
\hline & $\begin{array}{c}1966- \\
1970 \\
\end{array}$ & $\begin{array}{c}1971- \\
1975 \\
\end{array}$ & $\begin{array}{c}1976- \\
1979 \\
\end{array}$ & $\begin{array}{c}1980- \\
1984 \\
\end{array}$ & $\begin{array}{l}1985- \\
1990\end{array}$ & $\begin{array}{l}1991- \\
1999\end{array}$ & $\begin{array}{l}2000- \\
2005\end{array}$ \\
\hline \multicolumn{8}{|l|}{ Blue-collar positions } \\
\hline Agricultural & 10.1 & 10.2 & 9.1 & 6.2 & 6.8 & 4.1 & 3.3 \\
\hline Unqualified & 24.8 & 19.3 & 19.7 & 12.0 & 15.4 & 12.6 & 19.9 \\
\hline Qualified & 50.4 & 44.5 & 49.6 & 49.1 & 44.7 & 37.2 & 28.7 \\
\hline Highly qualified & 8.5 & 11.0 & 9.1 & 10.2 & 10.0 & 8.0 & 8.1 \\
\hline $\begin{array}{l}\text { Total share of blue- } \\
\text { collar positions }\end{array}$ & 93.8 & 85.0 & 87.5 & 77.5 & 76.9 & 61.9 & 60.0 \\
\hline \multicolumn{8}{|l|}{ White-collar positions } \\
\hline Simple tasks & 2.3 & 3.2 & 1.2 & 3.6 & 4.3 & 11.5 & 16.9 \\
\hline Qualified tasks & 2.3 & 4.3 & 2.4 & 8.4 & 7.1 & 10.7 & 8.8 \\
\hline Professional & 1.6 & 7.5 & 8.7 & 10.5 & 11.7 & 13.7 & 13.6 \\
\hline $\begin{array}{l}\text { Total share of white- } \\
\text { collar positions }\end{array}$ & 6.2 & 15.0 & 12.3 & 22.5 & 23.1 & 35.9 & 39.3 \\
\hline Self-employed & 0.0 & 0.0 & 0.4 & 0.0 & 0.0 & 2.2 & 0.7 \\
\hline Total & 100.0 & 100 & 100.2 & 100 & 100 & 100.0 & 100.0 \\
\hline $\mathrm{N}$ & 129 & 254 & 254 & 275 & 351 & 460 & 272 \\
\hline
\end{tabular}

\subsection{Occupational position at the first job}

The distributions of the occupational position at the first job also show continuous developments (see Table 7). There was, on the one hand, a constant increase of white-collar positions, both for females and males. For men, moreover, a significant expansion of these positions during the transition period can be observed. Among the male respondents who started their first job in the era of Perestroika, $23.1 \%$ took over a white-collar position, but this share increased to $35.9 \%$ 
in the first years of the transition period. On the other hand, a gender-specific segregation of bluecollar and white-collar professions occurred. The majority of male respondents started their first job in a blue-collar position, although this share was continuously declining. The majority of female respondents entered a white-collar position and between 2000 and 2005, only 17.8\% of the women entering working life started to work as a worker or as an agricultural employee.

The results also document that the developments reported above did not lead to an 'upgrading' of the occupational structure. The increase in white-collar positions took place primarily in the area of simple tasks. This holds true for females and males. Moreover, the share of blue-collar positions on the level of qualified workers decreased continuously. Thus, although there was a permanent increase in educational attainment, this development is not reflected by an increasing number of qualified blue- or white-collar positions.

\subsection{Determinants of the timing of entering working life}

The first multivariate analysis addresses the determinants of the length of the period between leaving the educational system and starting work (see Table 8). The estimates rest on a piecewise constant exponential survival regression. The length of the duration is measured in months. The central explanatory variables are the type of education before leaving the educational system and the period in which this event occurred. The place of living at the time of leaving school, the place of living at the time of participation in the first wave of the GGS and a period of military service between finishing school and starting work are used as control variables.

The results document that women who graduated from any kind of occupational school or training were at a significantly higher risk of entering working life as women who finished a tertiary education. This is not the case for women with a complete secondary education. Here, it took significantly longer before working life was entered. Many of these respondents initially tried to get a place at a university and had to look for a job after they were rejected. Men with a complete secondary education show the same pattern. Among the other male respondents, however, only graduates from Technical-Trade Schools and Secondary Technical-Trade Schools were at higher risk of entering working life as individuals finishing their studies at a university. In general, these results have to be interpreted cautiously, as they also document different pathways from a particular educational degree into the first job. During socialism, education at Technical-Trade Schools and Secondary Technical-Trade Schools was closely associated with distinct jobs in local factories and firms. Thus, many graduates from these schools moved from school-to-work within a short period. This was not the case for graduates from universities, however, as they were offered jobs all over the Soviet Union. 
Table 8

Determinants of the risk of entering working life after leaving school or university (Piecewise-constant exponential survival regression)

\begin{tabular}{|c|c|c|c|c|}
\hline & \multicolumn{2}{|c|}{ Females } & \multicolumn{2}{|c|}{ Males } \\
\hline & $\begin{array}{c}\text { Hazard } \\
\text { ratio }\end{array}$ & Sign. & $\begin{array}{c}\text { Hazard } \\
\text { ratio }\end{array}$ & Sign. \\
\hline \multicolumn{5}{|l|}{ Duration: } \\
\hline 1-3 months & 1 & & 1 & \\
\hline 4-6 months & 0.918 & 0.082 & 0.309 & 0.000 \\
\hline 7-9 months & 0.149 & 0.000 & 0.056 & 0.000 \\
\hline 10-12 months & 0.135 & 0.000 & 0.031 & 0.000 \\
\hline 13-18 months & 0.121 & 0.000 & 0.021 & 0.000 \\
\hline 19-24 months & 0.095 & 0.000 & 0.052 & 0.000 \\
\hline 25-36 months & 0.132 & 0.000 & 0.384 & 0.000 \\
\hline $37-48$ months & 0.114 & 0.000 & 0.223 & 0.000 \\
\hline 49 or more months & 0.049 & 0.000 & 0.108 & 0.000 \\
\hline \multicolumn{5}{|l|}{ Type of education: } \\
\hline Complete secondary & 0.590 & 0.000 & 0.752 & 0.000 \\
\hline Technical-Trade School & 1.420 & 0.000 & 1.288 & 0.006 \\
\hline Full-time professional training & 1.496 & 0.002 & 0.979 & 0.881 \\
\hline Secondary Technical-Trade School & 1.282 & 0.000 & 1.202 & 0.018 \\
\hline Specialized Secondary School & 1.257 & 0.000 & 0.937 & 0.423 \\
\hline Tertiary education & 1 & & 1 & \\
\hline Other education & 0.896 & 0.446 & 0.906 & 0.504 \\
\hline \multicolumn{5}{|l|}{ Cohort of leaving school: } \\
\hline $1966-1970$ & 2.090 & 0.000 & 1.638 & 0.000 \\
\hline $1971-1975$ & 2.162 & 0.000 & 1.470 & 0.000 \\
\hline $1976-1979$ & 2.062 & 0.000 & 1.543 & 0.000 \\
\hline $1980-1984$ & 2.038 & 0.000 & 1.250 & 0.004 \\
\hline $1985-1990$ & 1.676 & 0.000 & 0.976 & 0.745 \\
\hline $1991-1999$ & 1 & & 1 & \\
\hline $2000-2005$ & 0.816 & 0.009 & 0.915 & 0.310 \\
\hline \multicolumn{5}{|l|}{ Military service after leaving school } \\
\hline Yes & -- & & 0.693 & 0.000 \\
\hline No & -- & & 1 & \\
\hline \multicolumn{5}{|l|}{ Place of living at the time of leaving school: } \\
\hline Urban type village or village & 1 & & 1 & \\
\hline Town, city & 1.216 & 0.000 & 0.951 & 0.391 \\
\hline Regional, territorial or republican center & 1.402 & 0.000 & 1.176 & 0.007 \\
\hline \multicolumn{5}{|l|}{ Place of living at time of GGS interview: } \\
\hline Moscow or St. Petersburg & 1.010 & 0.875 & 1.181 & 0.057 \\
\hline Other Region & 1 & & 1 & \\
\hline Log Likelihood & \multicolumn{2}{|c|}{$-5,497.48$} & \multicolumn{2}{|c|}{$-3,334.25$} \\
\hline$\chi^{2}(\mathrm{df})$ & \multicolumn{2}{|c|}{$5,295.20(23)$} & \multicolumn{2}{|c|}{$2,629.89(24)$} \\
\hline Person months & \multicolumn{2}{|c|}{33,826} & \multicolumn{2}{|c|}{29,341} \\
\hline No. of events & \multicolumn{2}{|c|}{3,173} & \multicolumn{2}{|c|}{1,932} \\
\hline No. of subjects & \multicolumn{2}{|c|}{3,424} & \multicolumn{2}{|c|}{2,080} \\
\hline
\end{tabular}

Source: EES, own calculations

Table 8 also documents the effects of the different cohorts of leaving school or university on the risk of entering a first job. The cohort 1991 to 1999 was chosen as the reference category as we hypothesize that respondents graduating in this period are exposed to the lowest risk to start work. The results for female respondents support this hypothesis. Women who graduated during the era of state socialism were at a significantly higher risk of entering working life as women 
who have left the educational system during the 1990s. The sharp decline between the period of Perestroika and the first phase of Russia's transition is especially remarkable. Moreover, women's situation did not improve. Women who left school or university during the first years of the new century document a rate of entering working life that is significantly lower than the rate for women in the reference category.

The estimates for men show a different pattern. Until the period of Perestroika, men were at a significantly higher risk of entering working life compared to men who graduated in the 1990s. However, the rate already decreased in the first half of the 1980s and there is no significant difference between the rates of male graduates during the period of Perestroika and the first and second phase of the transition period. Thus, male rates of entering working life did not vary significantly between 1985 and 2005. Women, however, had to face a continuous decline of the risk of moving from school to work within a short period.

One question that emerges from these results is whether graduates from different levels of education were exposed to different risks of entering working life during the different periods of state socialism and transition. Thus, the population of female and male respondents is separated into two groups. One group covers all individuals who graduated during the period of socialism. The other group addresses all individuals who have left the educational system during the transition period. Survival regressions with the same set of covariates as reported in Table 8 are estimated for each group. Due to the separation, however, new reference categories for the periods of finishing school had to be defined. These are 1966 to 1970 for the first group and 1991 to 1999 for the second group.

The estimates for female respondents are documented in Table 9. According to the group of women who left the educational system during socialism, the effects of the type of education document again that graduates from any kind of secondary vocational school or professional training were at a significantly higher risk of entering working life than women who have finished university. Young women with a degree in complete secondary education, however, had to search longer for a first job. This pattern changed significantly during the transition period. There were no significant differences of the risks between graduates from vocational schools and universities. Only graduates from academic secondary schools continued to take significantly longer to enter working life. 
Table 9

Determinants of the risk of entering working life after leaving school or university Female respondents

(Piecewise-constant exponential survival regression)

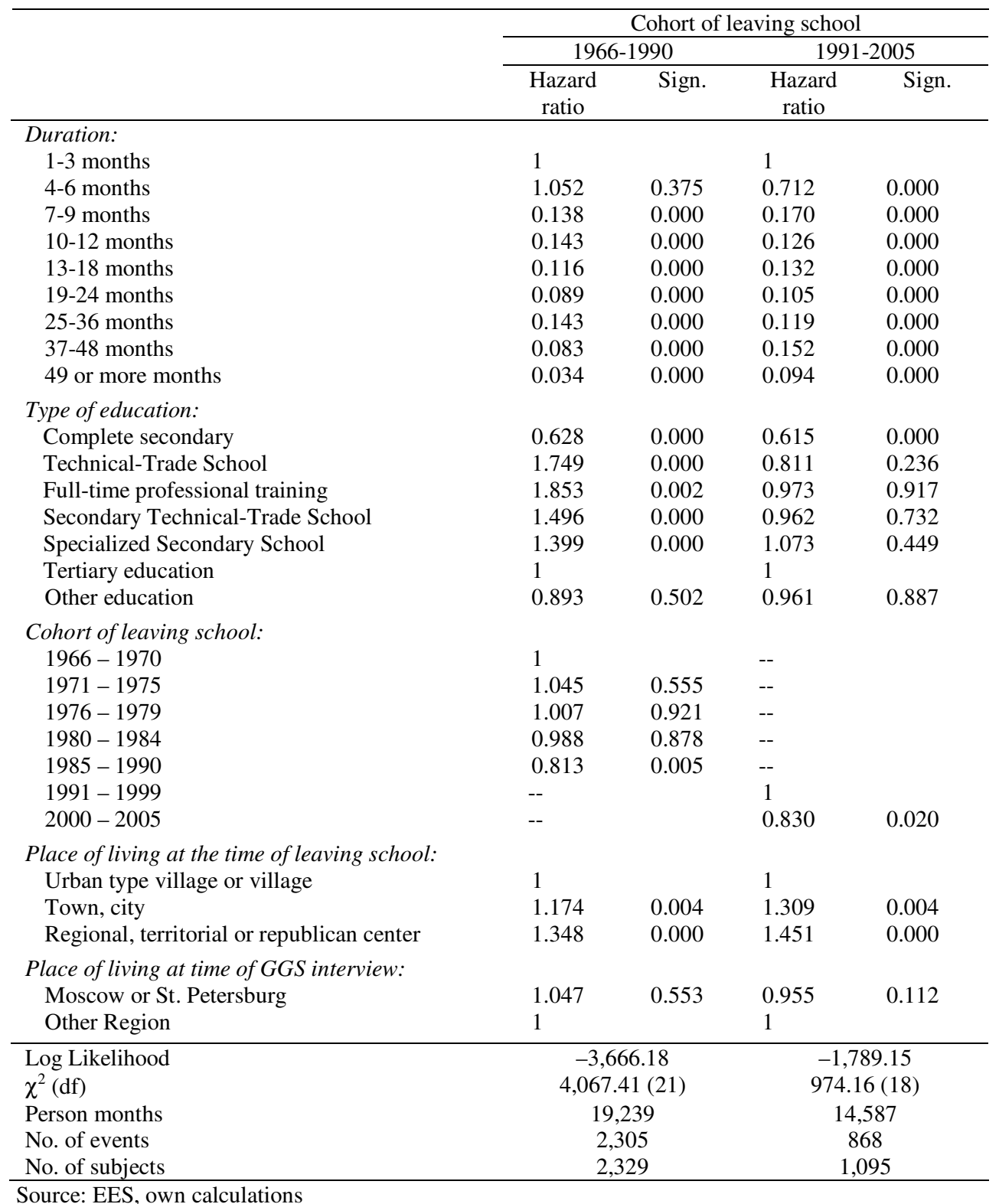

The effects of the cohort variables show that already during the time of Perestroika, women were at a significantly lower risk of entering working life upon graduating between 1966 and 1970. This risk continued to decline during the transition period. Thus, women who left school or university at the beginning of the new century faced a significantly lower risk to start work as during the 1990s, although the Russian economy started to recover after 1999. 
Table 10

Determinants of the risk of entering working life after leaving school or university Male respondents

(Piecewise-constant exponential survival regression)

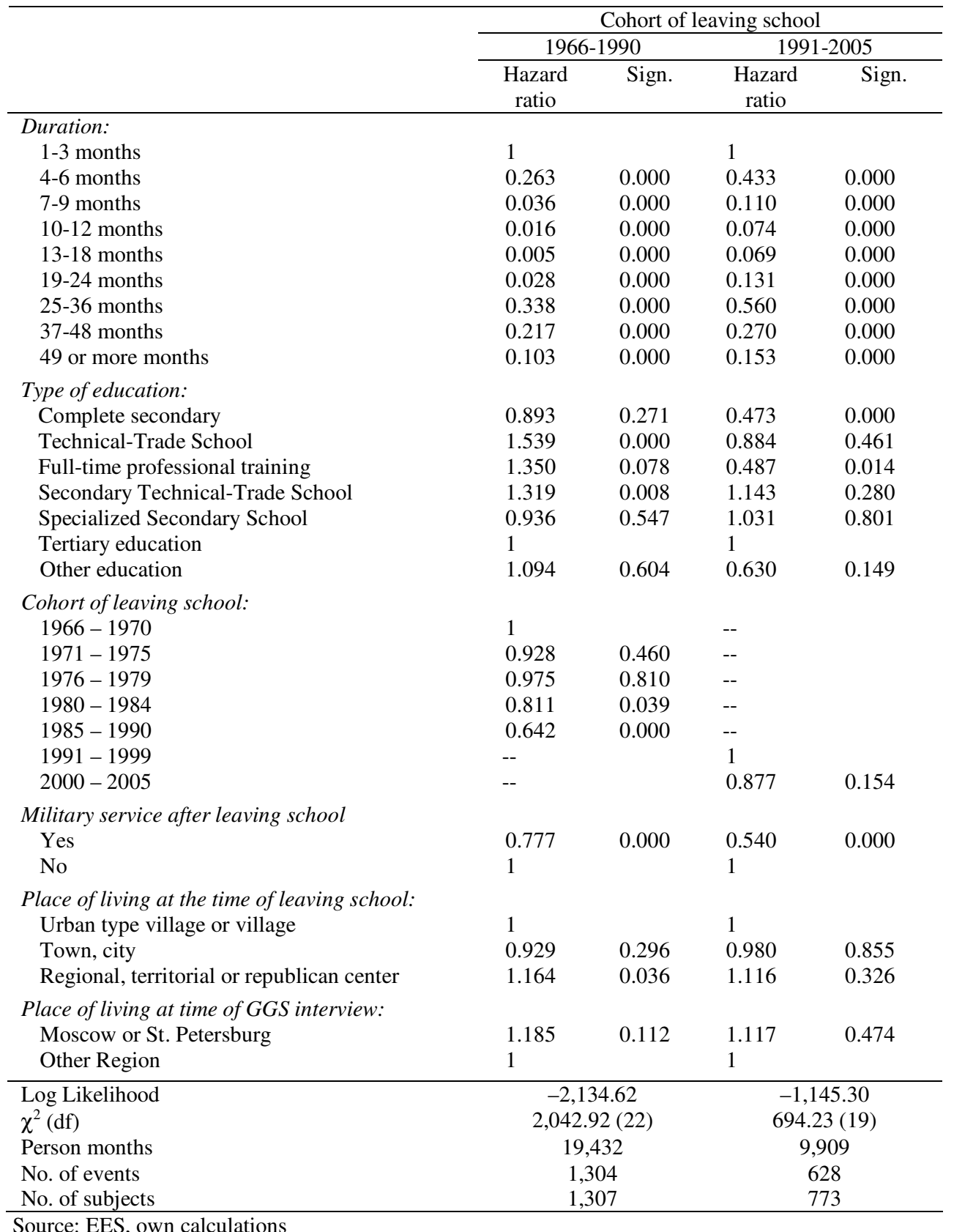

The estimates for men show both similar and different patterns of effects when compared to women (see Table 10). During socialism, males graduating from schools that provided basic occupational training, like Technical-Trade Schools, were at a significantly higher risk of entering working life than were individuals who had finished university. This result documents again the 
close relationship between vocational schools and local employers. However, looking for a first job did not take significantly longer for individuals with a degree in complete secondary education. Consequently, it was relatively easy for many of these young men to find a job without particular vocational requirements. This changed during the transition period. Graduates from academic secondary schools or with professional training were at a significantly lower risk to enter working life. Moreover, the significant positive effects of Technical-Trade Schools and Secondary Technical-Trade Schools disappeared.

Contrary to the results for women, men's risk to start work within a short period already began to decline in the early 1980s. This process also continued during the transition period, but the differences of the hazard rates for the periods 1991-1999 and 2000-2005 are not significant.

\subsection{Determinants of the employment situation after graduation}

In a second step, the analyses explore the determinants of the employment situation after graduating from school or university by estimating multinomial logit regressions. For female respondents, the situations of 'work', 'housewife', 'unemployment', and 'other situation' are considered. For male respondents, the analyses address 'work', 'unemployment', 'military service', and 'other situation'. The situation of moving directly to work builds the reference category for both groups of respondents.

The set of explanatory variables is the same as the one that was used in the survival regressions in the last section. However, for primarily technical reasons that emerged during the estimation procedures, the reference categories changed. The effects of the kind of education have to be interpreted relative to respondents who graduated from Specialized Secondary Schools and the effects of the cohorts are relative to individuals who have left school or university between 1966 and 1975. Moreover, in order to improve the clarity of the presentation of the results, Table 11, Table 12, and Table 13 do not report the estimates for the category 'other situation' of the dependent variable. $^{12}$

Throughout the periods of state socialism and transition, female respondents with a primarily academic education, i.e. who received a degree in complete secondary education or who finished university, had a significantly higher probability of becoming housewives compared to graduates with a semi-professional education from Specialized Secondary Schools (see Table 11). Graduates from secondary academic schools also became unemployed more often. The effects of the cohort variables show - starting with the period of Perestroika - a continuous increase in the probability of staying at home as a housewife after leaving the educational system. According to

\footnotetext{
${ }^{12}$ Tables that cover all estimates are available from the authors upon request.
} 
Table 11

Determinants of employment situation after leaving school or university

(Multinomial logit)

\begin{tabular}{|c|c|c|c|c|c|c|c|c|}
\hline & \multicolumn{4}{|c|}{ Females } & \multicolumn{4}{|c|}{ Males } \\
\hline & \multicolumn{2}{|c|}{ Housewife } & \multicolumn{2}{|c|}{ Unemployment } & \multicolumn{2}{|c|}{ Unemployment } & \multicolumn{2}{|c|}{$\begin{array}{c}\text { Military } \\
\text { service }\end{array}$} \\
\hline & $\begin{array}{l}\text { Odds } \\
\text { ratio }\end{array}$ & Sign. & $\begin{array}{l}\text { Odds } \\
\text { ratio }\end{array}$ & Sign. & $\begin{array}{l}\text { Odds } \\
\text { ratio }\end{array}$ & Sign. & $\begin{array}{l}\text { Odds } \\
\text { ratio }\end{array}$ & Sign. \\
\hline \multicolumn{9}{|l|}{ Kind of education: } \\
\hline Complete secondary & 4.392 & 0.000 & 5.040 & 0.000 & 1.249 & 0.375 & 0.058 & 0.000 \\
\hline Technical-Trade School & 1.015 & 0.957 & 0.900 & 0.780 & 0.513 & 0.049 & 0.306 & 0.000 \\
\hline Full-time professional training & 1.070 & 0.874 & 1.002 & 0.998 & 1.013 & 0.978 & 0.417 & 0.007 \\
\hline $\begin{array}{l}\text { Secondary Technical-Trade } \\
\text { School }\end{array}$ & 1.239 & 0.259 & 1.528 & 0.072 & 0.755 & 0.255 & 0.421 & 0.000 \\
\hline Specialized Secondary School & 1 & & 1 & & 1 & & 1 & \\
\hline Tertiary education & 1.605 & 0.008 & 0.773 & 0.347 & 0.486 & 0.014 & 0.345 & 0.000 \\
\hline Other education & 2.505 & 0.017 & 2.282 & 0.104 & 0.298 & 0.109 & 0.283 & 0.001 \\
\hline \multicolumn{9}{|l|}{ Cohort of leaving school: } \\
\hline $\begin{array}{l}1966-1970 \\
1971-1975\end{array}$ & 1 & & 1 & & 1 & & 1 & \\
\hline $1976-1979$ & 1.253 & 0.266 & 0.682 & 0.147 & 0.836 & 0.580 & 0.628 & 0.070 \\
\hline $1980-1984$ & 1.003 & 0.990 & 0.448 & 0.012 & 0.520 & 0.097 & 1.660 & 0.013 \\
\hline $1985-1990$ & 1.559 & 0.022 & 0.522 & 0.028 & 1.460 & 0.180 & 1.909 & 0.001 \\
\hline $1991-1999$ & 4.847 & 0.000 & 3.154 & 0.000 & 3.062 & 0.000 & 1.461 & 0.052 \\
\hline $2000-2005$ & 5.468 & 0.000 & 5.379 & 0.000 & 2.711 & 0.000 & 0.664 & 0.117 \\
\hline \multicolumn{9}{|l|}{$\begin{array}{l}\text { Place of living at the time of } \\
\text { leaving school: }\end{array}$} \\
\hline Urban type village or village & 1 & & 1 & & 1 & & 1 & \\
\hline Town, city & 0.547 & 0.000 & 1.097 & 0.610 & 1.355 & 0.148 & 1.323 & 0.066 \\
\hline $\begin{array}{l}\text { Regional, territorial or } \\
\text { republican center }\end{array}$ & 0.365 & 0.000 & 0.771 & 0.170 & 1.054 & 0.806 & 0.582 & 0.001 \\
\hline \multicolumn{9}{|l|}{$\begin{array}{l}\text { Place of living at time of GGS } \\
\text { interview: }\end{array}$} \\
\hline Moscow or St. Petersburg & 0.499 & 0.008 & 0.546 & 0.053 & 0.349 & 0.017 & 0.648 & 0.113 \\
\hline Other region & 1 & & 1 & & 1 & & 1 & \\
\hline Log Likelihood & \multicolumn{4}{|c|}{$-2,387.29$} & \multicolumn{4}{|c|}{$-1,965.45$} \\
\hline$\chi^{2}(\mathrm{df})$ & \multicolumn{4}{|c|}{$637.06(42)$} & \multicolumn{4}{|c|}{$474.41(42)$} \\
\hline $\mathrm{N}$ & \multicolumn{4}{|c|}{3,308} & \multicolumn{4}{|c|}{1,984} \\
\hline
\end{tabular}

unemployment, the cohort variables show a rigorous change after the breakdown of state socialism. During the 1980s, women faced a probability of unemployment that was significantly lower than during the period 1966 to 1975 . Starting from 1991, however, this probability rose sharply and continued to increase during Russia's period of economic recovery after 1999.

The estimates for male respondents show different results. Only respondents with a simple occupational education, i.e. graduates from Technical-Trade Schools, faced a significantly higher probability of becoming unemployed as graduates from Secondary Special Schools. Graduates from the latter kind of school, however, had to deal with the highest risk of being called for military service immediately after finishing school. This might be caused by the graduate's age struc- 
Table 12

Determinants of employment situation after leaving school or university - female respondents (Multinomial logit)

\begin{tabular}{|c|c|c|c|c|c|c|c|c|}
\hline & \multicolumn{8}{|c|}{ Cohort of leaving school } \\
\hline & \multicolumn{4}{|c|}{$1966-1990$} & \multicolumn{4}{|c|}{$1991-2005$} \\
\hline & \multicolumn{2}{|c|}{ Housewife } & \multicolumn{2}{|c|}{ Unemployment } & \multicolumn{2}{|c|}{ Housewife } & \multicolumn{2}{|c|}{ Unemployment } \\
\hline & $\begin{array}{l}\text { Odds } \\
\text { ratio }\end{array}$ & Sign. & $\begin{array}{l}\text { Odds } \\
\text { ratio }\end{array}$ & Sign. & $\begin{array}{l}\text { Odds } \\
\text { ratio }\end{array}$ & Sign. & $\begin{array}{l}\text { Odds } \\
\text { ratio }\end{array}$ & Sign. \\
\hline \multicolumn{9}{|l|}{ Type of education: } \\
\hline Complete secondary & 4.453 & 0.000 & 10.307 & 0.000 & 3.144 & 0.000 & 2.128 & 0.012 \\
\hline $\begin{array}{l}\text { Technical-Trade School, full- } \\
\text { time professional training }\end{array}$ & 0.544 & 0.123 & 0.980 & 0.973 & 1.987 & 0.041 & 1.354 & 0.485 \\
\hline $\begin{array}{l}\text { Secondary Technical-Trade } \\
\text { School }\end{array}$ & 1.031 & 0.913 & 1.859 & 0.174 & 1.418 & 0.183 & 1.491 & 0.163 \\
\hline Specialized Secondary School & 1 & & 1 & & 1 & & 1 & \\
\hline Tertiary education & 1.453 & 0.191 & 1.460 & 0.491 & 1.639 & 0.035 & 0.549 & 0.060 \\
\hline \multicolumn{9}{|l|}{ Cohort of leaving school: } \\
\hline $\begin{array}{l}1966-19 / 0 \\
1971-1975\end{array}$ & 1 & & 1 & & 1 & & 1 & \\
\hline $1976-1979$ & 1.248 & 0.294 & 0.726 & 0.243 & -- & & -- & \\
\hline $1980-1984$ & 1.063 & 0.787 & 0.511 & 0.039 & -- & & -- & \\
\hline $1985-1990$ & 1.629 & 0.016 & 0.626 & 0.125 & -- & & -- & \\
\hline $1991-1999$ & -- & & -- & & 1 & & 1 & \\
\hline $2000-2005$ & -- & & -- & & 1.106 & 0.599 & 1.740 & 0.014 \\
\hline \multicolumn{9}{|l|}{$\begin{array}{l}\text { Place of living at the time of } \\
\text { leaving school: }\end{array}$} \\
\hline Urban type village or village & 1 & & 1 & & 1 & & 1 & \\
\hline Town, city & 0.497 & 0.000 & 1.193 & 0.475 & 0.639 & 0.034 & 1.080 & 0.783 \\
\hline $\begin{array}{l}\text { Regional, territorial or } \\
\text { republican center }\end{array}$ & 0.393 & 0.000 & 0.679 & 0.157 & 0.396 & 0.000 & 1.031 & 0.911 \\
\hline \multicolumn{9}{|l|}{$\begin{array}{l}\text { Place of living at time of } G G S \\
\text { interview: }\end{array}$} \\
\hline Moscow or St. Petersburg & 0.356 & 0.017 & 0.821 & 0.622 & 0.612 & 0.168 & 0.354 & 0.036 \\
\hline Other region & 1 & & 1 & & 1 & & 1 & \\
\hline Log Likelihood & \multicolumn{4}{|c|}{$-1,361.96$} & \multicolumn{4}{|c|}{-950.62} \\
\hline$\chi^{2}(\mathrm{df})$ & \multicolumn{4}{|c|}{$384.95(30)$} & \multicolumn{4}{|c|}{$120.75(24)$} \\
\hline $\mathrm{N}$ & \multicolumn{4}{|c|}{2,304} & \multicolumn{4}{|c|}{943} \\
\hline \multirow[b]{2}{*}{ Source: EES, own calculations } & payme & $\begin{array}{l}\text { r witho } \\
\text { ion' are }\end{array}$ & $\begin{array}{l}\text { ut paym } \\
\text { not rep }\end{array}$ & & & & & \\
\hline & & & & & & & & \\
\hline
\end{tabular}

ture, as $75 \%$ of them finished education at an age of at least 18.5 years. Similar to female respondents, a male's probability of becoming unemployed grew significantly at the start of Russia's transition period. Contrary to women, however, a male's situation improved slightly after 1999, as the probability of becoming unemployed decreased. Moreover, the rise of unemployment at the beginning of the transition period was not as sharp as for female graduates. A male's probability of having no job right after education had already started to grow during the period of Perestroika, although this effect is not significant.

In order to identify period-specific effects of educational attainment on the employment situation after leaving school or university, subgroups of respondents were built as previously done for the survival regressions in the last section. Table 12 and Table 13 document the results. 
Table 13

Determinants of employment situation after leaving school or university - male respondents (Multinomial logit)

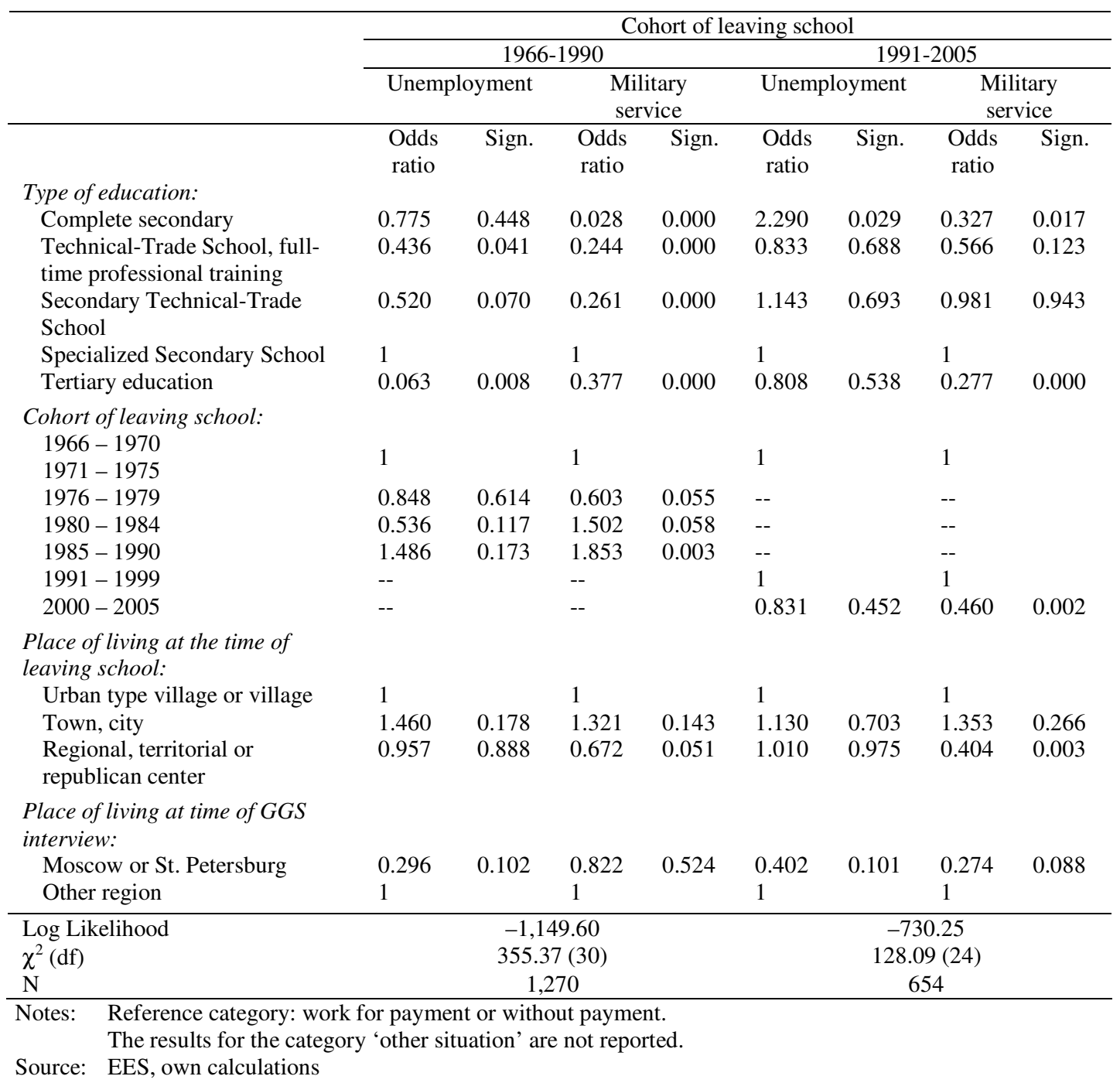

Small cell sizes, however, made it unavoidable to summarize all graduates from Technical Trade Schools and full-time professional training into one variable and to exclude from the analyses all respondents with 'another education'.

During socialism, primarily females with a degree in complete secondary education faced the lowest probability of entering working life directly after leaving school (see Table 12). Degrees from these schools normally led to a place at a university. Consequently, there were no direct paths to particular jobs and women had to handle more often intermediate periods of staying at home as housewives or of being unemployed. During the transition period, educational degrees show different effects on women's employment situation. On the one hand, women with 
basic occupational qualifications from Technical-Trade Schools or professional training, but also women graduating from universities, became housewives with a significantly higher probability than graduates from Secondary Special Schools. On the other hand, the situation of becoming unemployed did not change for individuals with a degree in complete secondary education in comparison to the period of socialism. They still faced a high probability of having no job after finishing school. However, this did not hold for graduates from universities, as members of this group of respondents show the lowest risk of becoming unemployed.

Male respondents document again a different pattern (see Table 13). During socialism, graduates from Secondary Special Schools faced the lowest risk of having no job immediately after leaving school. However, this effect is also caused by the fact that this group of respondents had to handle the highest risk of being called for military service. These patterns changed to some extent during the transition period. Similar to female respondents, males with a degree in complete secondary education had a higher probability of becoming unemployed. Graduates from Specialized Secondary Schools were still - along with graduates from Secondary TechnicalTrade Schools - at high risk of being called for military service.

\subsection{Determinants of the occupational position in the first job}

The last set of multivariate analyses addresses the determinants of the occupational position in the first job. It was one special characteristic of the Soviet Union that particular educational degrees led to particular occupational positions in the employment hierarchy. According to Gerber $(2003,246)$, there were three typical paths. Pupils at Technical-Trade Schools were trained for positions as skilled manual workers, graduates from Specialized Secondary Schools moved primarily to low and medium white-collar positions, and the purpose of tertiary institutions was to train professionals.

In order to identify these paths, a multinomial logit regression is estimated. The dependent variable is the first occupational position. It is summarized in three categories: the category 'qualified blue-collar' addresses the positions of qualified and highly qualified workers, 'qualified white-collar' covers white-collar positions with qualified tasks and professionals, and 'low level employees' summarizes the positions of agricultural workers, unskilled workers, and white-collar employees with simple tasks. The latter category builds the reference category. A more refined representation of the first occupational position is not possible because of small numbers of cases in some subgroups. For the same reason, respondents who have visited a Technical-Trade School or a full-time professional training have to be summarized. 
Table 14

Determinants of first occupational position (Multinomial logit)

\begin{tabular}{|c|c|c|c|c|c|c|c|c|}
\hline & \multicolumn{4}{|c|}{ Females } & \multicolumn{4}{|c|}{ Males } \\
\hline & \multicolumn{2}{|c|}{$\begin{array}{l}\text { Qualified blue- } \\
\text { collar }\end{array}$} & \multicolumn{2}{|c|}{$\begin{array}{l}\text { Qualified white- } \\
\text { collar }\end{array}$} & \multicolumn{2}{|c|}{$\begin{array}{l}\text { Qualified blue- } \\
\text { collar }\end{array}$} & \multicolumn{2}{|c|}{$\begin{array}{l}\text { Qualified white- } \\
\text { collar }\end{array}$} \\
\hline & $\begin{array}{l}\text { Odds } \\
\text { ratio }\end{array}$ & Sign. & $\begin{array}{l}\text { Odds } \\
\text { ratio }\end{array}$ & Sign. & $\begin{array}{l}\text { Odds } \\
\text { ratio }\end{array}$ & Sign. & $\begin{array}{l}\text { Odds } \\
\text { ratio }\end{array}$ & Sign. \\
\hline \multicolumn{9}{|l|}{ Kind of education: } \\
\hline Complete secondary & 0.328 & 0.000 & 0.115 & 0.000 & 0.205 & 0.000 & 0.116 & 0.000 \\
\hline $\begin{array}{l}\text { Technical-Trade School, full- } \\
\text { time professional training }\end{array}$ & 1.822 & 0.000 & 0.185 & 0.000 & 0.753 & 0.151 & 0.070 & 0.000 \\
\hline $\begin{array}{l}\text { Secondary Technical-Trade } \\
\text { School }\end{array}$ & 2.216 & 0.000 & 0.110 & 0.000 & 1.323 & 0.130 & 0.222 & 0.000 \\
\hline Specialized Secondary School & 1 & & 1 & & 1 & & 1 & \\
\hline Tertiary education & 0.758 & 0.276 & 2.097 & 0.000 & 0.450 & 0.002 & 3.162 & 0.000 \\
\hline Other education & 0.907 & 0.783 & 0.258 & 0.000 & 0.351 & 0.002 & 0.340 & 0.013 \\
\hline \multicolumn{9}{|l|}{ Cohort of entering working life: } \\
\hline $\begin{array}{l}1966-1970 \\
1971-1975\end{array}$ & 1 & & 1 & & 1 & & 1 & \\
\hline $1976-1979$ & 1.111 & 0.509 & 1.206 & 0.236 & 1.081 & 0.698 & 0.837 & 0.614 \\
\hline $1980-1984$ & 0.668 & 0.014 & 0.942 & 0.702 & 1.332 & 0.178 & 2.433 & 0.006 \\
\hline $1985-1990$ & 0.783 & 0.140 & 1.283 & 0.105 & 0.915 & 0.642 & 1.337 & 0.339 \\
\hline $1991-1999$ & 0.307 & 0.000 & 0.828 & 0.198 & 0.526 & 0.001 & 1.018 & 0.951 \\
\hline $2000-2005$ & 0.211 & 0.000 & 0.513 & 0.000 & 0.292 & 0.000 & 0.316 & 0.000 \\
\hline \multicolumn{9}{|l|}{ Unemployment episode: } \\
\hline Yes & 1.188 & 0.174 & 0.812 & 0.078 & 0.791 & 0.063 & 0.517 & 0.001 \\
\hline No & 1 & & 1 & & 1 & & 1 & \\
\hline \multicolumn{9}{|l|}{ Episode of maternity leave: } \\
\hline Yes & 1.063 & 0.575 & 1.099 & 0.345 & -- & & -- & \\
\hline No & 1 & & 1 & & -- & & -- & \\
\hline \multicolumn{9}{|l|}{ Housewife episode: } \\
\hline Yes & 0.687 & 0.001 & 0.657 & 0.000 & -- & & -- & \\
\hline No & 1 & & 1 & & -- & & -- & \\
\hline \multicolumn{9}{|l|}{ Episode of military service: } \\
\hline Yes & -- & & -- & & 1.137 & 0.359 & 0.330 & 0.000 \\
\hline No & -- & & -- & & 1 & & 1 & \\
\hline \multicolumn{9}{|l|}{$\begin{array}{l}\text { Place of living at the time of } \\
\text { leaving school: }\end{array}$} \\
\hline Urban type village or village & 1 & & 1 & & 1 & & 1 & \\
\hline Town, city & 1.268 & 0.088 & 1.081 & 0.527 & 2.388 & 0.000 & 1.340 & 0.191 \\
\hline $\begin{array}{l}\text { Regional, territorial or } \\
\text { republican center }\end{array}$ & 1.731 & 0.000 & 1.475 & 0.001 & 3.146 & 0.000 & 1.672 & 0.019 \\
\hline \multicolumn{9}{|l|}{$\begin{array}{l}\text { Place of living at time of } G G S \\
\text { interview: }\end{array}$} \\
\hline Moscow or St. Petersburg & 1.349 & 0.110 & 1.249 & 0.216 & 1.089 & 0.725 & 1.682 & 0.087 \\
\hline Other region & 1 & & 1 & & 1 & & & \\
\hline Log Likelihood & \multicolumn{4}{|c|}{$-2,713.88$} & \multicolumn{4}{|c|}{$-1,480.21$} \\
\hline$\chi^{2}(\mathrm{df})$ & \multicolumn{4}{|c|}{$1,328.62(32)$} & \multicolumn{4}{|c|}{$914.70(30)$} \\
\hline $\mathrm{N}$ & \multicolumn{4}{|c|}{3,174} & \multicolumn{4}{|c|}{1,922} \\
\hline
\end{tabular}

According to the results in Table 14, especially women document a close association between the kind of education and the first occupational position throughout the whole period of observation. One the one hand, women with basic vocational education or training entered quali- 
fied blue-collar positions with a significantly higher probability as women from Specialized Secondary Schools. On the other hand, graduates from the latter type of school and from universities tended to be primarily placed in first jobs in qualified white-collar positions. Fore males, this segregation is less clearly pronounced. Male respondents with basic vocational qualifications did not enter qualified blue-collar positions with a higher probability as graduates from Specialized Secondary Schools. This result rests on the fact that Specialized Secondary Schools offered occupational qualifications for males that are located in the areas of blue- and white collar jobs. This is not the case for women. Here, Specialized Secondary Schools teach semi-professions that are primarily located in the area of employees. Similar to women, however, male's white-collar positions were primarily filled with individuals with a semi-professional or professional education. The overall negative effects of female and male respondents with a complete secondary education show that these young people tended to start their employment career on unqualified or low-level blue- and white-collar jobs.

The estimates for the cohorts of entering working life show a substantive downgrading of the first occupational positions during the transition period. Compared to the cohort 1966-1975, both females and males entered qualified blue-collar positions with a significant lower probability after the breakdown of socialism. However, this development is not compensated by a significant increase of respondents entering qualified white-collar positions. Moreover, the probability of entering these positions continued to decline after 1999. Thus, young people graduating from the educational system during the transition period faced an increasing probability of starting their occupational careers on unqualified or low level occupational positions.

In order to identify differences between the periods of socialism and transition, separate estimates were undertaken for the female and male respondents who entered working life between 1966 and 1990 or between 1991 and 2005 (see Table 15 and Table 16). We firstly discuss the results for females. Women who started to work during socialism tend to show a declining probability of entering qualified blue-collar positions, but there is only a significant effect for the entry cohort 1980 to 1984 . The effects of variables representing educational degrees repeat the pattern already documented in Table 14. Females with no educational training entered - relative to graduates from Secondary Special Schools - qualified blue- and white-collar positions significantly less often and graduates from any kind of basic occupational education or training were more often located in qualified blue-collar positions and started to work with a lower probability at qualified white-collar positions.

At the beginning of Russia's economic recovery after 1999, there was a lower probability for women to start work on a qualified white-collar position compared to women who entered the 
Table 15

Determinants of first occupational position - female respondents (Multinomial logit)

\begin{tabular}{|c|c|c|c|c|c|c|c|c|}
\hline & \multicolumn{8}{|c|}{ Cohort of entering working life } \\
\hline & \multicolumn{4}{|c|}{$1966-1990$} & \multicolumn{4}{|c|}{1991 to 2005} \\
\hline & \multicolumn{2}{|c|}{$\begin{array}{l}\text { Qualified blue- } \\
\text { collar }\end{array}$} & \multicolumn{2}{|c|}{$\begin{array}{l}\text { Qualified white- } \\
\text { collar }\end{array}$} & \multicolumn{2}{|c|}{$\begin{array}{l}\text { Qualified blue- } \\
\text { collar }\end{array}$} & \multicolumn{2}{|c|}{$\begin{array}{l}\text { Qualified white- } \\
\text { collar }\end{array}$} \\
\hline & $\begin{array}{l}\text { Odds } \\
\text { ratio }\end{array}$ & Sign. & $\begin{array}{l}\text { Odds } \\
\text { ratio }\end{array}$ & Sign. & $\begin{array}{l}\text { Odds } \\
\text { ratio }\end{array}$ & Sign. & $\begin{array}{l}\text { Odds } \\
\text { ratio }\end{array}$ & Sign. \\
\hline \multicolumn{9}{|l|}{ Kind of education: } \\
\hline Complete secondary & 0.339 & 0.000 & 0.086 & 0.000 & 0.180 & 0.000 & 0.284 & 0.000 \\
\hline $\begin{array}{l}\text { Technical-Trade School, full- } \\
\text { time professional training }\end{array}$ & 2.024 & 0.000 & 0.164 & 0.000 & 0.943 & 0.886 & 0.269 & 0.000 \\
\hline $\begin{array}{l}\text { Secondary Technical-Trade } \\
\text { School }\end{array}$ & 2.711 & 0.000 & 0.120 & 0.000 & 1.173 & 0.566 & 0.097 & 0.000 \\
\hline Specialized Secondary School & 1 & & 1 & & 1 & & 1 & \\
\hline Tertiary education & 0.783 & 0.443 & 1.887 & 0.004 & 0.565 & 0.197 & 2.531 & 0.000 \\
\hline Other education & 0.806 & 0.607 & 0.259 & 0.000 & 1.074 & 0.911 & 0.228 & 0.032 \\
\hline \multicolumn{9}{|l|}{ Cohort of entering working life: } \\
\hline $\begin{array}{l}1966-1970 \\
1971-1975\end{array}$ & 1 & & 1 & & -- & & -- & \\
\hline $1976-1979$ & 1.108 & 0.527 & 1.174 & 0.321 & -- & & -- & \\
\hline $1980-1984$ & 0.657 & 0.012 & 0.892 & 0.475 & -- & & -- & \\
\hline $1985-1990$ & 0.767 & 0.114 & 1.201 & 0.246 & -- & & -- & \\
\hline $1991-1999$ & -- & & -- & & 1 & & 1 & \\
\hline $2000-2005$ & -- & & -- & & 0.691 & 0.153 & 0.639 & 0.012 \\
\hline \multicolumn{9}{|l|}{ Unemployment episode: } \\
\hline Yes & 1.343 & 0.050 & 0.939 & 0.679 & 0.980 & 0.937 & 0.632 & 0.018 \\
\hline No & 1 & & 1 & & 1 & & 1 & \\
\hline \multicolumn{9}{|l|}{ Episode of maternity leave: } \\
\hline Yes & 1.083 & 0.517 & 1.071 & 0.561 & 0.895 & 0.680 & 1.301 & 0.161 \\
\hline No & 1 & & 1 & & 1 & & 1 & \\
\hline \multicolumn{9}{|l|}{ Housewife episode: } \\
\hline Yes & 0.619 & 0.000 & 0.696 & 0.003 & 1.094 & 0.702 & 0.550 & 0.000 \\
\hline No & 1 & & 1 & & 1 & & 1 & \\
\hline \multicolumn{9}{|l|}{$\begin{array}{l}\text { Place of living at the time of } \\
\text { leaving school: }\end{array}$} \\
\hline Urban type village or village & 1 & & 1 & & 1 & & 1 & \\
\hline Town, city & 1.224 & 0.198 & 1.100 & 0.527 & 1.503 & 0.218 & 0.978 & 0.919 \\
\hline $\begin{array}{l}\text { Regional, territorial or } \\
\text { republican center }\end{array}$ & 1.644 & 0.250 & 1.514 & 0.004 & 2.219 & 0.014 & 1.326 & 0.191 \\
\hline \multicolumn{9}{|l|}{$\begin{array}{l}\text { Place of living at time of the } \\
\text { interview: }\end{array}$} \\
\hline Moscow or St. Petersburg & 1.421 & 0.311 & 1.223 & 0.354 & 1.171 & 0.688 & 1.243 & 0.456 \\
\hline Other region & 1 & & 1 & & 1 & & 1 & \\
\hline Log Likelihood & \multicolumn{4}{|c|}{$-1,959.21$} & \multicolumn{4}{|c|}{-729.93} \\
\hline$\chi^{2}(\mathrm{df})$ & \multicolumn{4}{|c|}{$989.89(28)$} & \multicolumn{4}{|c|}{$303.52(24)$} \\
\hline $\mathrm{N}$ & \multicolumn{4}{|c|}{2,266} & \multicolumn{4}{|c|}{908} \\
\hline
\end{tabular}

labor market during the period of crisis in the 1990s. The effects of educational degrees show a pattern similar to that during socialism, but the effects of basic vocational schools on the probability of entering a qualified blue-collar position became not significant. In the area of whitecollar positions, therefore, traditional associations between the kind of education and the first 
Table 16

Determinants of first occupational position - male respondents (Multinomial logit)

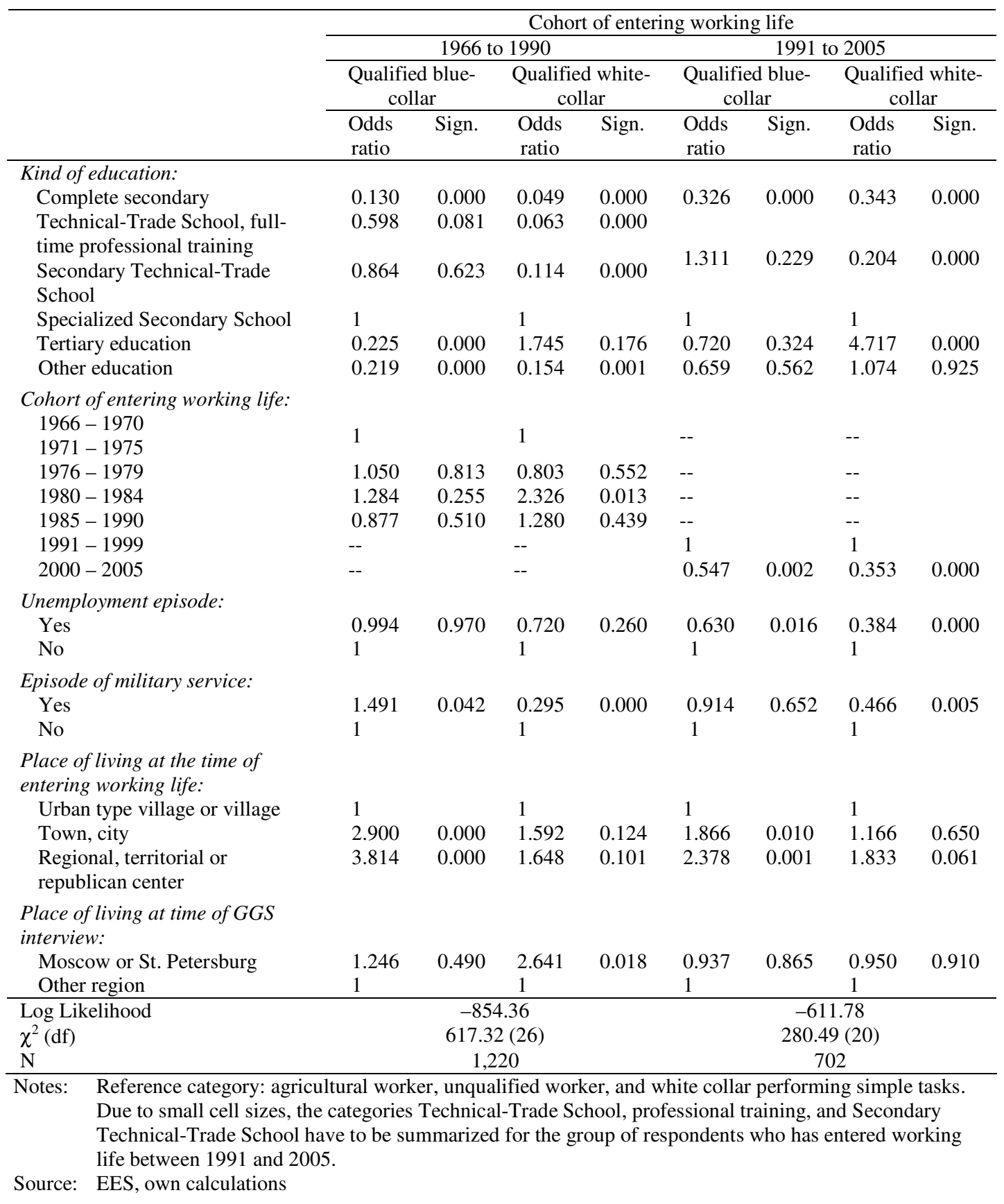

occupational position continued to exist after the breakdown of socialism. However, this is not the case for blue-collar jobs.

For male respondents, the effects of the variables representing the cohorts of entering working life during socialism do not display general trends (see Table 16). There was only a significant increase of qualified white-collar and professional positions between 1980 and 1984 com- 
pared to the period 1966 to 1975 . The effects of variables representing educational degrees show again a pattern of less significant influences of basic vocational schools and training on entering qualified blue-collar positions as they do for women. The analysis addressing Russia's period of transition confirms the result that compared to male respondents who started to work during the period of economic crisis, graduates entering working life during the period of economic recovery, entered a qualified blue- or white-collar position less often. However, the pattern of associations between educational degree and first occupational position remained, in general, unchanged.

Thus, both women and men document an overall stable pattern of paths from educational degrees to occupational positions that continued to exist during the transition period. There is a persistently strong relationship between education and first occupational position, although the transition from school-to-work became more difficult and risky as the increasing shares of unemployment episodes and higher ages at entering working life document.

\section{Concluding remarks}

The purpose of the paper was to characterize the transition from school-to-work in Russia and to identify changes of this process due to the breakdown of the Soviet system and the subsequent political and economic transformations. This characterization took place in the background of two hypothetical perspectives. Because of the abrupt introduction of a neo-liberal economic order, the subsequent economic crises, the emergence of private companies and new branches, and the retreat of the state as a central coordinator, we expected changes in the transition from school-to-work that arose immediately after the end of state socialism. However, there is also theoretical and empirical evidence that institutions are inert and alter only slowly and that the institutions in Russia became only inadequately adjusted to the new economic order. Thus, we also expected less rigorous and gradual changes in the transition from school-to-work and a continuation of the general pattern of the process as it occurred during socialism.

The empirical analyses identified elements of both continuity and change. According to educational degrees, women continued to leave the educational system with, on average, higher, more white-collar-oriented degrees than did men. However, an increasing number of men and women decided, during the 1990s, to continue their stay in the educational system by starting university studies. Thus, a significant number of young adults graduated from a university at the beginning of the new century. This development rests on various aspects. The economic crisis in the 1980s and the associated problems in the employment system provided a strong incentive to not leave the educational system. Moreover, places at universities were no longer centrally 
planned or restricted. Many young adults recognized that a higher education could improve their professional chances upon entering the newly emerging labor markets.

As individuals started to stay longer in the educational system, they also started to graduate and to enter the employment system at higher ages. However, this development is primarily observable since the year 2000. In the 1990s, the median age at leaving school and entering working life follow developments that had already started during the period of socialism. However, higher ages at entering working life are not only the expression of a better-educated population of young adults. They also express problems during the transition from school-to-work. After the breakdown of state socialism, both females and males faced a higher risk of not entering the employment system within a short period, as was usual during the era of socialism. The probability of becoming unemployed rose sharply. Women especially were confronted with the situation that the process of entering working life became less stable.

This is also documented by the fact that graduates started their employment career more often in unqualified blue- and white-collar positions during the transition period. This induces the risk of short-term and unstable employment, as well as of blocked career opportunities. Again, especially women had to face this situation. This is consistent with the conclusions of other authors (Gerber and Mayorova 2006, Ashwin and Yakubovich 2005) who state that women are more pressed, but are also more willing, to take over low-level jobs. However, there are also elements of continuity. The characteristic paths of particular educational degrees into particular occupational positions continued to exist during the transition process. Moreover, the descriptive and multivariate analyses do not document an abrupt, but rather a more delayed change of the process of entering working life. After the breakdown of the Soviet system, there was - with the exception of unemployment - no immediate radical change of the distribution of educational attainments, the timing of entering working life, or the distribution of first occupational positions. The changes took place gradually with the consequence that for the young people who entered working life after 1999, the pattern of the transition from school-to-work differed most strongly from the pattern during socialism.

Altogether, the results lead to the conclusion that young people who entered working life in the transition period were exposed to increasing risks of unemployment and unstable incomes. Thus, the transition from school-to-work in Russia resembled the transitions in western industrialized societies. However, these risks are not an expression of radical institutional change but of a process of stepwise adaptations of the educational and employment system to the new economic order. 


\section{Literature}

Adam, Jan. 1989. Economic reforms in the Soviet Union and Eastern Europe since the 1960s. Houdmills and London: Macmillan.

Allmendinger, Jutta. 1989. Educational systems and labor market outcomes. European Sociological Review 5: 231-50.

Ashwin, Sarah and Valery Yakubovich. 2005. Cherchez la Femme: Women as supporting actors in the Russian labour market. European Sociological Review 21: 149-64.

Avis, George. 1983. Access to higher education in the Soviet Union. In Soviet education in the 1980s, ed. J. J. Tomiak, 199-239. London and Canberra: Croom Helm.

Becker, Gary S. 1975. Human capital. New York: Columbia University Press.

Bole, Dorothee and Béla Greskovits. 2006. Capitalism without compromise: Strong business and weak labor in Eastern Europe's new transnational industries. Studies in Comparative International Development 41(1): 3-25.

Blau, Peter M. and Otis Dudley Duncan. 1966. The American occupational structure. New York: Wiley.

Blossfeld, Hans-Peter. 1989. Kohortendifferenzierung und Karriereprozeß - Eine Längsschnittstudie über die Veränderung der Bildungs- und Berufschancen im Lebenslauf. Campus: Frankfurt and New York.

Blossfeld Hans-Peter, Erik Klijzing, Melinda Mills, and Karin Kurz, ed. 2005. Globalization, uncertainty and youth in society. London et al.: Routledge.

Brauns, Hildegard, Markus Gangl, and Stefani Scherer. 1999. Education and unemployment: Patterns of labour market entry in France, the United Kingdom, and West Germany. Working Paper 9, Mannheimer Zentrum für Europäische Sozialforschung, Mannheim.

Bühler, Christoph, Vladimir Magun, Polina M. Kozyreva, Mikhail S. Kosolapov, Oksana Sinyavskaya, Vladimir Shkolnikov, Hill Kulu, Andres Vikat, and Rene Houle. 2007. The Education and Employment Survey for Russia: Survey Instruments. Max Planck Institute for demographic Research, Rostock.

Burawoy, Michael and Pavel Krotov. 1992. The Soviet transition from socialism to capitalism: Worker control and economic bargaining in the wood industry. American Sociological Review 57: 16-38.

Clarke, Simon. 2004. A very Soviet form of capitalism? The management of holding companies in Russia. Post-Communist Economies 16: 405-22.

Coleman, James S. 1988. Social capital in the creation of human capital. American Journal of Sociology 94: S95-S120.

Connor, Walter D. 1991. The accidental proletariat. Workers, politics, and crisis in Gorbachev's Russia. Princeton: Princeton University Press.

Elliott, Julian and Jonathan Tudge. 2007. The impact of the west on post-Soviet Russian education: Change and resistance to change. Comparative Education 43(1): 93-112.

Ericson, Richard E. 1991. The classical Soviet-type economy: Nature of the system and implications for reform. Journal of Economic Perspectives 5: 11-27.

Ericson, Richard E. 1984. The "second economy" and resource allocation under central planning. Journal of Comparative Economics 8: 1-24.

Estévez-Abe, Margarita. 2005. Gender bias in skills and social policies: The Varieties of Capitalism perspective on sex segregation. Social Politics 12(2): 180-215.

Eyraud, Francois, David Marsden, and Jean-Jacques Silvestre. 1990. Occupational and internal labor markets in Britain and France. International Labour Review 129: 501-17.

Feldmann, Magnus. 2006. Emerging Varieties of Capitalism in transition countries: Industrial 
relations and wage bargaining in Estonia and Slovenia. Comparative Political Studies 39(7): 829-54.

Furstenberg, Frank F. Jr., Rubén G. Rumbaut, and Richard A. Settersten, Jr. 2005. On the frontier of adulthood. Emerging themes and new directions. In On the frontier of adulthood: theory, research, and public policy, ed. Richard A. Settersten, Jr., Frank F. Furstenberg, Jr., and Rubén G. Rumbaut, 3-25. Chicago and London: University of Chicago Press.

Gallie, Duncan. 2007. Production regimes and the quality of employment in Europe. Annual Review of Sociology 33: 85-104.

Gangl, Markus. 2001. European patterns of labour market entry. A dichotomy of occupationalized vs. non-occupationalized systems? European Societies 3: 471-94.

Gangl, Markus. 2000. European perspectives on labour market entry: A matter of institutional linkages between training systems and labour markets? Mannheimer Zentrum für Europäische Sozialforschung, Mannheim.

Ganzeboom, Harry B.G. and Paul Nieuwbeerta. 1999. Access to education in six Eastern European countries between 1940 and 1985. Results of a cross-national survey. Communist and Post-Communist Studies 32: 339-57.

Gerber, Theodore P. 2003. Loosening links? School-to-work transitions and institutional change in Russia since 1970. Social Forces 82: 241-76.

Gerber, Theodore P. and Michael Hout. 1995. Educational stratification in Russia during the Soviet period. American Journal of Sociology 105: 611-60.

Gerber, Theodore P. and Olga Mayorova. 2006. Dynamic gender differences in a post-socialist labor market: Russia, 1991-1997. Social Forces 84: 2047-75.

Granovetter, Mark S. 1995. Getting a job: A study of contacts and careers. $2^{\text {nd }}$ edition, Chicago: University of Chicago Press.

Grigorenko, Elena L. 1999. Current trends in education in Russia: Preliminary outcomes indicative for students' cognitive development. International Journal of Psychology 34(3): 17584.

Grossman, Gregory. 1963. Notes for a theory of command economy. Soviet Studies 15(2): 10123.

Hall, Pater A. and David Soskice. 2001. An introduction to varieties of capitalism. In Varieties of capitalism. The institutional foundations of comparative advantage, ed. Peter A. Hall and David Soskice, 1-68. New York: Oxford University Press.

Heyns, Barbara and Ireneusz Bialecki. 1993. Educational inequalities in postwar Poland. In Persistent inequality. Changing educational attainment in thirteen countries, ed. Yossi Shavit and Hans-Peter Blossfeld, 303-33. Boulder: Westview Press.

Ivancic, Angela. 2000. Education and shifts between labour-market states in the transition from the socialist to the market economy: The Slovenian case. European Sociological Review 16: 403-25.

Kalter, Frank and Irena Kogan. 2006. Ethnic inequalities at the transition from school to work in Belgium and Spain: Discrimination or self-exclusion? Research in Social Stratification and Mobility 24: 259-74.

Katus, Kalev, Allan Puur, and Luule Sakkeus. 2005. Transition from adulthood in Estonia: Evidence from the FFS. Globalife, Working Paper 24, Otto-Friedrich-Universität Bamberg, Faculty of Sociology and Economy.

Kennedy, Robert E. 1997. A tale of two economies: Economic restructuring in post-socialist Poland. World Development 25: 841-65. 
Kerckhoff, Alan C. 2000. Transition from school to work in comparative perspective. In Handbook of the sociology of education, ed. Maureen T. Hallinan, 453-74. New York: Kluwer Academic/Plenum Publishers.

Kerckhoff, Alan C. 1996. Building conceptual and empirical bridges between studies of educational and labor force careers. In Generating social stratification, ed. Alan C. Kerckhoff, 37-56. Boulder: Westview Press.

Kerckhoff, Alan C. 1995. Institutional arrangements and stratification processes in industrial societies. Annual Review of Sociology 15: 323-47.

King, Lawrence. 2007. Central European capitalism in comparative perspective. In Beyond Varieties of Capitalism. Conflict, contradictions, and complementarities in the European economy, ed. Bob Hancké, Martin Rhodes, and Mark Thatcher, 307-27. Oxford: Oxford University Press.

King, Lawrence. 2002. Postcommunist divergence: A comparative analysis of the transition to capitalism in Poland and Russia. Studies in Comparative International Development 37(3): 3-34.

Kogan, Irena and Marge Unt. 2005. Transition from school to work in transition economies. European Societies 7: 219-53.

Konietzka, Dirk and Johannes Huinink. 2003. Die De-Standardisierung einer Statuspassage? Zum Wandel des Auszugs aus dem Elternhaus und des Übergangs in das Erwachsenenalter in Westdeutschland. Soziale Welt 54: 285-311.

Kornai, János. 1986. The Hungarian reform process: Visions, hopes, and reality. Journal of Economic Literature 24: 1687-737.

Kornai, János. 1984. Bureaucratic and market organization. Osteuropa 29: 306-19

Kornai, János. 1980. Economics of shortage. Volume A. Amsterdam et al.: North-Holland

Korpi, Walter. 2006. Power resources and employer-centered approaches in explanations of welfare states and Varieties of Capitalism. World Politics 58: 167-206.

Kuczynski, Waldemar. 1978. The state enterprise under Socialism. Soviet Studies 30: 313-35.

Lane, David. 2000. What kind of capitalism for Russia? A comparative analysis. Communist and Post-Communist Studies 33: 485-504.

Littlejohn, Gary. 1988. Central planning and market relations in socialist societies. Journal of Development Studies 24(4): 75-101.

Litwack, John M. 1991. Legality and market reform in Soviet-type economies. Journal of Economic Perspectives 5: 77-89.

Marsden, David. 1997. The approaches of economists to the relationship between training and work. The case of Great Britain. In Education and work in Great Britain, Germany, and Italy, ed. Anette Jobert, Catherine Marry, Lucie Tanguy, and Helen Rainbird, 192-207. London: Routledge.

Mayer, Karl Ulrich. 1997. Notes on a comparative political economy of life courses. Comparative Social Research 16: 203-26.

Mayer, Karl Ulrich and Glenn R. Carroll. 1987. Jobs and classes: Structural constraints on career mobility. European Sociological Review 3: 14-38.

Matthews, Mervyn. 1983. Long term trends in Soviet education. In Soviet education in the 1980s, ed. J. J. Tomiak, 1-23. London and Canberra: Croom Helm.

Matthews, Mervyn. 1982. Education in the Soviet Union. Policies and institutions, Boston and Sidney: George Allen \& Unwin.

McCann, Leo and Gregory Schwartz. 2006. Terms and conditions apply. Management restructuring and the global integration of post-socialist societies. International Journal of Human Resource Management 17: 1339-52. 
Meier, Artur. 1989. Universals and particularities of socialist educational systems: The transition from school to work in the German Democratic Republic and the Soviet Union. In Crossnational research in Sociology, ed. M. L. Kohn, 167-84. Newbury Perk: Sage.

Müller, Walter and Markus Gangl, ed. 2004. Transitions from education to work in Europe. The integration of youth into EU labour markets. Oxford: Oxford University Press

Müller, Walter and Yossi Shavit. 1998. The institutional embeddedness of the stratification process: A comparative study of qualifications and occupations in thirteen countries. In: From school to work. A comparative analysis of educational qualifications and occupational destinations ed. Yossi Shavit and Walter Müller, 1-48. Oxford: Clarendon Press.

Nee, Victor G. 1989. A theory of market transition: From redistribution to markets in state socialism. American Sociological Review 54: 663-81.

Nee, Victor G. and Yang Cao. 2002. Postsocialist inequalities: The causes of continuity and discontinuity. Research in Social Stratification and Mobility 19: 3-39.

Nee, Victor G. and Yang Cao. 1999. Path dependent social transformation: Stratification in hybrid mixed economies. Theory and Society 28: 799-834.

O'Dell, Felicity. 1983. Vocational education in the USSR. In Soviet education in the 1980s, ed. J. J. Tomiak, 106-42. London and Canberra: Croom Helm.

Peng, Mike W. and Peggy Sue Heath. 1996. The growth of the firm in planned economies in transitions: Institutions, organizations, and strategic choice. Academy of Management Review 21: 492-528.

Polanyi, Karl. 1944. The great transformation. New York: Rinehart

Powell, Raymond P. 1977. Plan execution and the workability of Soviet planning. Journal of Comparative Economics 1: 51-76.

Poznanski, Kazimierz Z. 2001. Building capitalism with Communist tools: Eastern Europe's defective transition. East European Politics \& Societies 15: 320-55.

Rychlewski, Eugeniusz. 1973. The investment system of a Socialist economy. Eastern European Economics 12(1): 3-44.

Saar, Ellu. 2005. New entrants on the Estonian labor market: A comparison with the EU. European Societies 7: 513-46.

Sahlins, Marshall D. 1965. On the sociology of primitive exchange. In The relevance of models for social anthropology, ed. Michael Banton, 139-236. London: Travistock.

Scherer, Stefani. 2004. Stepping-stones or traps? The consequences of labour market entry positions on future careers in West Germany, Great Britain, and Italy. Work, Employment \& Society 18: 369-94.

Scherer, Stefani. 2001. Early career patterns: A comparison of Great Britain and West Germany. European Sociological Review 17: 119-44.

Shavit, Yossi and Walter Müller, ed. 1998. From school to work. A comparative study of educational qualifications and occupational destinations. Oxford: Clarendon Press.

Simonová, Natalie and Dominik Antonowicz. 2006. Czech and Polish higher education - from bureaucracy to market competition. Czech Sociological Review 42(3): 517-36.

Solga, Heike and Dirk Konietzka. 1999. Occupational matching and social stratification. Theoretical insights and empirical observations taken from a German-German comparison. European Sociological Review 15: 25-47.

Soroko, Eugeny and Dirk Konietzka. 2006. Report on the external validation of the "Education and Employment Survey" on Russia. MPIDR Working Paper, WP-2006-028, Rostock.

Soskice, David. 2005. Varieties of Capitalism and cross-national gender differences. Social Politics 12(2): 170-179. 
Soulsby, Anna and Ed Clark. 2006. Changing patterns of employment in post-socialist organizations in Central and Eastern Europe: Management action in a transitional context. International Journal of Human Resource Management 17: 1396-410.

Stark, David. 1992. From system identity to organizational diversity: Analyzing social change in Eastern Europe. Contemporary Sociology 21: 299-304.

Stark, David. 1991. Path dependence and privatization strategies in East Central Europe. East European Politics \& Societies 6: 17-54.

Stark, David and László Bruszt. 1998. Postsocialist pathways. Transforming politics and property in East Central Europe. Cambridge: Cambridge University Press.

Svejnar, Jan. 1991. Microeconomic issues in the transition to a market economy. Journal of Economic Perspectives 5: 123-38.

Szelényi, Ivan and Eric Kostello. 1996. The market transition debate: Toward a synthesis? American Journal of Sociology 101: 1082-96.

Szelényi, Szonja and Karen Aschaffenburg. 1993. Inequalities in educational opportunity in Hungary. In Persistent inequality. Changing educational attainment in thirteen countries, ed. Yossi Shavit and Hans-Peter Blossfeld, 273-302. Boulder: Westview Press.

Titma, Mikk and Ellu Saar. 1995. Regional differences in Soviet secondary education. European Sociological Review 11: 37-58.

Titma, Mikk, Nancy Brandon Tuma, and Kadi Roosma. 2003. Education as a factor in intergenerational mobility in Soviet society. European Sociological Review 19: 281-97.

UNICEF. 2007. TransMONEE 2007 database. www.unicef-irc.org/databases/transmonee/

Uunk, Wilfried, Bogdan W. Mach, and Karl Ulrich Mayer. 2005. Job mobility in the former East and West Germany. The effects of state-socialism and labor market composition. European Sociological Review 21: 393-408.

Vanhuysse, Pieter. 2007. Workers without power: Agency, legacies, and labour decline in East European Varieties of Capitalism. Czech Sociological Review 43(3): 495-522.

Vikat, Andres, Zsolt Spéder, Gijs Beets, Francesco Billari, Christoph Bühler, Aline Désesquelles, Tineke Fokkema, Jan M. Hoem, Alphonse MacDonald, Gerda Neyer, Ariane Pailhé, Antonella Pinnelli, and Anne Solaz. 2007. Generations and Gender Survey: Towards a better understanding of relationships and processes in the life course. Demographic Research 17: 389-439.

Walker, Charles. 2006. Managing vocational education in the youth labour market in post-Soviet Russia. International Journal of Human Resource Management 17: 1426-40.

Wolbers, Maarten H. J. 2007. Patterns of Labour Market Entry. A Comparative Perspective on School-to-Work Transitions in 11 Countries. Acta Sociologica 50(3): 189-210.

Ziegler, Rolf. 1990. The Kula: Social order, barter and ceremonial exchange. In Social institutions. Their emergence, maintenance and effects, ed. Michael Hechter, Karl-Dieter Opp, and Reinhard Wippler, 141-68. Berlin and New York: de Gruyter. 